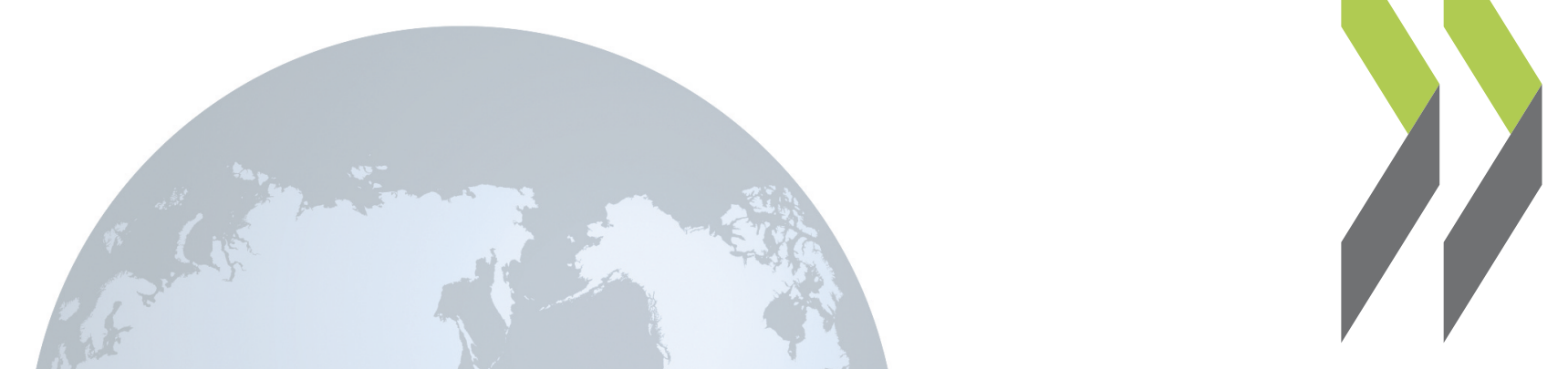

OECD Labour Market and Social Policy Occasional Papers No. 6

\title{
Equal Pay for Work
} of Comparable Worth: The Experience of Industrialised

\section{OECD}


LABOUR MARKET AND SOCIAL POLICY ' OCCASIONAL PAPERS

\author{
$\mathrm{N}^{\circ} 6$ \\ EQUAL PAY FOR WORK \\ OF COMPARABLE WORTH: \\ THE EXPERIENCE OF \\ INDUSTRIALISED COUNTRIES
}

(0)COE

刺

OESCD

PARIS 1991 
GERERAL DISTRIBUTION

OCDE/GD (91) 183

IABOUR MARKET AND SOCIAL POLICY OCCASIONAL PAPERS

No. 6

EQUAL PAY FOR WORK OF COMPARABLE WORTH THE EXPERIENCE OF INDUSTRIALISED COUNTRIES

ORGANISATION FOR ECONOMIC CO-OPERATION AND DEVELOPMENT

Paris 1991

39966

FOR TECHNICAL REASONS, GRAPHS, TABLES \& FACSIMILES ARE NOT AVAILABLE ON OLIS 

DIRECTORATE FOR SOCIAL AFFAIRS, MANPOWER AND EDUCATION

OCCASTONAL PAPERS

This series is designed to make available to a wider readership selected labour market and social policy studies prepared for use within the OECD. Authorship is usually collective, but principal writers are named. The papers are generally available only in their original language -- English or Erench - - with a summary in the other.

Comment on the series is welcome, and should be sent to the Directorate for Social Affairs, Manpower and Education, 2, rue André-Pascal, 75775 PARIS CEDEX 16, France. Additional, limited copies are available on request.

The opinions expressed and arguments employed here are the responsibility of the author(s) and do not necessarily represent those of the OECD.

Copyright OECD 1991. 
LABOUR MARKET AND: SOCIAL POLICY: OCCASIONAL PAPERS

(Already available, free of charge)

NO. I AN ECONOMIC FRAMEWORK FOR THE EVALUATION OF CHILD CARE POLICY (1990) (Donald Verry)

No. 1 UN CADRE ÉCONOMIQUE POUR L'ÉVALUATION DES POLITIQUES DE GARDE D'ENFANT (1990) (Donald Verry).

NO. 2 HEALTH AND PENSION REFORM IN JAPAN (1990)

NO. 3 WRONGFUL TERMINATION LITIGATION IN THE UNTTED STATES AND ITS EFFECT ON THE EMPLOYMENT RELATIONSHIP (1990) (Susan R. Mendelsohn)

No. 4 STATISTICS OF ANNUAL EARNINGS IN OEGD COUNTRIES (1990). (David. Grubb)

NO. 5 WAGE DIFFERENTIALS, ENTRY AND THE JOB GENERATION PROCESS IN GERMANY (1990) (Tito Boeri)

\section{Mailing List for \\ Labour Market and Social Policy Occasional Papers \\ Please include the following name on the mailing list: \\ (write in capitals)}

Name
Organisation

Address

Country

This form should be returned to:

Labour Market and Social Policy Occasional Papers Directorate for Social Affairs, Manpower and Education OECD

2, rue André-Pascal

75775 PARIS CEDEX 16

FRANCE 


\section{A SELECTION OF OECD PUBLICATIONS ALSO AVAILABLE}

\section{"OECD SOCIAL POLICY STUDIES" SERIES}

NO. 1 SOCIAL EXPENDITURE 1960-1990: Problems of Growth and Control (1985) Out of print in English. French text available under the title: Dépenses sociales 1960-1990. Problemes de croissance et de maltrise. $\left(\begin{array}{lllll}81 & 85 & 01 & 2\end{array}\right)$ ISBN $92-64-22656-7,100$ pp. $\quad £ 7.50$ US\$15.00 FF75 DM33

NO. 2 MEASURING HEALTH CARE 1960-1983: Expenditure, Costs and Performance (1985) (81 8506 1)ISBN 92-64-12736-4, 162 pp.

Out of print. Available on microfiche edition.

Price per microfiche:

$£ 2.50 \quad$ US\$4.50 FF20 DM8

NO. 3 LIVING CONDITIONS IN OECD COUNTRIES: A Compendium of SOCial Indicators (1986) (81 8504 1)ISBN $92-64-12734-8,166$ pp. $\$ 6.50$ US\$13.00 FF65 DM29

No. 4 FINANCING AND DELIVERING HEALTH CARE: A Comparative Analysis of OECD Countries (1987)

(81 8702 1) ISBN 92-64-12973-1, 102 pp.

$£ 11.00$ US\$19.00 FF90 DM37

NO. 5 REFORMING PUBLIC PENSIONS (1988)

(81 8804 1) ISBN $92-64-13123-\mathrm{X}, 250 \mathrm{pp}$.

$£ 15.50$ US\$29.00 FF130 DM56

NO. 6 THE FUTURE OF SOCIAL PROTECTION (1988)

(81 8803 1) ISBN $92-64-13152-3,64$ pp.

$£ 8.50$ US\$15.50 FF70 DM31

NO. 7 HEALTH CARE SYSTEMS IN TRANSITION: The Search for Efficiency (1990)

(81 8905 1) ISBN $92-64-13310-0,206$ pp. $\$ 17.00$ US\$30.00 FF140 DM55

No. 8 LONE PARENT FAMILIES: The ECONomic Challenge (1990).

(81 8904 1) ISBN $92-64-13303-8,252$ pp. $\quad £ 20.00$ US\$34.00 FF160 DM66

\section{EMPLOYMENT}

OECD EMPLOYMENT OUTLOOK July 1990 (published annually)

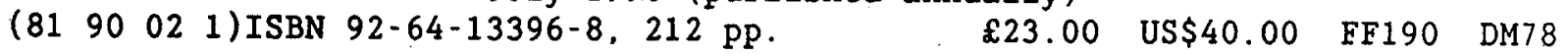

THE INTEGRATION OF WOMEN INTO THE ECONOMY (1985)

( 818505 1) ISBN $92-64-12735-6,184$ pp. $\quad £ 10.00 \quad$ US\$20.00 FF100 DM44

MEASURES TO ASSIST THE LONG-TERM ONEMPLOYED -- Recent Experience in SOMe OECD Countries (1988)

(81 8806 1) ISBN $92-64-13134-5,100$ pp. $\quad £ 7.50 \quad$ US\$13.50 FF60 DM26

LABOUR MARKET FLEXIBILITY: Trends in Enterprises (1989)

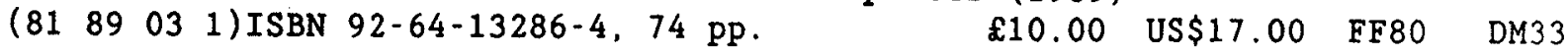


MECHANISMS FOR JOB (REATION: LesSons from the United States (1989)

(81 8801 1) ISBN 92. 64-13186-8, $228 \mathrm{pp}$.

£14.50 US\$25.50 FF120 DM50

NEW TECHNOLOGY IN THE 1990S: A Socio-Economic Strategy (1989)

$(818807$ 1) ISBN 9? 64.13180.9, $130 \mathrm{pp}$.

$£ 11.00$ US\$19.00 FF90 DM37

LABOUR MARKE'T POLICTES FOR THE 1990S (1990)

(819001 1) ISBN 92-64-13363-1, $130 \mathrm{pp}$.

$£ 13.00$ US\$23.00 FF110 DM43

ENTERPRISING WOMEN (1990)

(819002 1) I.SBN 92-64-13436-5, $110 \mathrm{pp}$.

$£ 9.50$ US\$19.00 FF95 DM42

\section{DEMOGRAPHY}

AGEING POPULATIONS: The Social Policy Implications (1988)

( 81888202 1) ISBN $92-64-13113-2.90 \mathrm{pp}$.

$£ 12.00$ US\$22.00 FF100 DM43

MIGRATION: THE DEMOGRAPHIC ASPECTS (1991)

$(819003$ 1) ISBN 92-64-13439-5, $92 \mathrm{pp}$.

$£ 15.00$ US\$26.00 FF125 DM48

\section{CHILD CARE}

CHILDREN AND SOCIETY: Issues for Pre-School Reforms (1981)

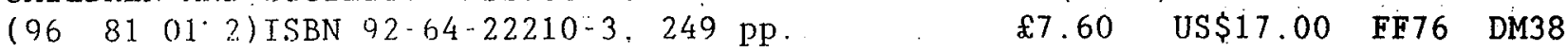
(out of print)

CARING FOR YOUNG CHILDREN (1982)

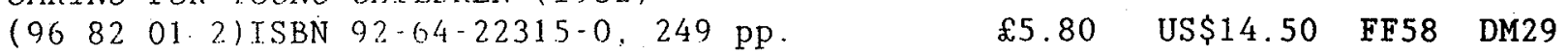

(out of print)

"CHILD CARE IN-OECD COUNTRIES", in OECD Employment Outlook, July 1990, chapter 5 .

Prices charged at the OECD Bookshop

THE OECD CATALOGUE OF PUBLICATIONS and supplements will be sent

free of charge on request addressed either to OECD Publications Service,

$\therefore$ rue André-Pascal, 75775 PARIS CEDEX 16

or to the OECD Distributor in your country 
Equal pay is no longer discussed simply in relation to equal work. Equal pay for work of equal value has, in some countries, become a critical objective of policies against discrimination in employment. This report describes the degree to which the concept of work of equal value has been incorporated into equal pay legislation and collective bargaining in thirteen OECD countries. It also emphasizes the problems encountered when implementing this type of policy. and attempts to establish its real and potential impact.

This document was produced by the Women's Bureau (Department of Employment. Education and Training. Australia) for the Working Party on the Role of Women in the Economy. It is based on information available on April $30,1989$.

La question de l'égalité des salaires ne se pose plus seulement aujourd'hui en termes d'un même travail. L'égalité des salaires pour un travail de valeur comparable est devenue dans certains pays un objectif central des politiques de lutte contre la discrimination dans 1'emploi. Ce document décrit dans quelle mesure le concept de travail de valeur comparable a été intégré dans la législation sur l'égalité des salaires et la négociation collective dans treize pays de 1 OCDE. Il souligne les problèmes de mise en oeuvre d'une telle politique et essaie de dégager sa portée réelle et potentielle.

Le document a été élaboré par le Women's Bureau (Department of Employment. Education and Training. Australie) pour le Groupe de travail sur le rôle des femmes clans 1 'économie. Les informations contenues dans le document ont été arrêtées an 30 avril 1989. 


\section{CONTENTS}

\section{Page}

I. INTRODUCTION 1

II. THE FAMII.Y WAGE

III. . GENERAL LEGISLATTVE AND INDUSTRIAL CONTEXT 6

1. Equal Pay Legislation 6

2. Definition of Work Value and Lepislative Experience. 16

3. Jndustrial Experience . 33

IV. IDENTIFYING DEMANDS ON EMPLOYEES 43

V. IMPACT OF LEGISLATIVE AND INDUSTRIAL RESPONSES
TO PAY EOUTTY

1. Population Affected by Legislation and
Industrial Agreements

2. Implementation Issues 47

3. Impact Fvaluations 49

VI. CONCLUSION $\quad 54$

VII. NOTES AND REFERENCES 57

VIII. TABLES AND FIGURES $\quad 59-74$ 



\section{INTRODUCTION}

The considerable legislative and industrial activity surrounding pay equity issues in the $1970 \mathrm{~s}$ and $80 \mathrm{~s}$ has created a basis for analysis of different strategic approaches to the implementation of pay equity in a number of OECD countries. This has involved identifying not only national wage-fixing systems and national legislation, but also the way in which each constrains the operation of the other. While the analysis necessarily touches on the relationship between pay and employment patterns such as occupational segregation, its focus is mainly institutional and its approach largely descriptive. The equal employment opportunity and affirmative action activity which is essential to supplement pay equity measures is not considered here at length.

There is a number of factors, including unavailability and non-comparability of data, which restrict analysis and reduce the confidence with which conclusions can be drawn. It has for example recently been argued that any analysis based on observed wages rather than the distribution of wage offers is likely to result in a serious undervaluation of the extent of wage discrimination (1). In addition part-time and casual work and outwork have not been considered here, and non-wage benefits have been referred to only briefly. These matters both deserve and require separate analysis.

The paper addresses four related matters:

- The historical, industrial and legislative context of gender wage differentials;

- The impact of legislative and industrial responses to pay equity;

-- Issues in comparing men's and women's work; and

- Issues in the implementation of pay equity.

The general case for pay equity for women has been clearly accepted in terms of the industrial and legislative context in all OECD countries. Of the countries contributing to this study (2), all but the United States have signed the ILO Equal Remuneration Convention (No. 100) since it was adopted in 1951 , and all have some form of equal pay legislation. The basic approach to pay equity is, however, still uneven across countries, varying between equal pay for similar work and equal pay for work of equal value; and approaches to implementation vary accordingly.

In all participating countries supplying appropriate data, full-time women workers across all industries receive between just over half and just over 80 per cent of the hourly pay received by men. This discrepancy in earnings is partly attributed to the characteristic patterns of women's labour force participation, which in turn reflects social attitudes, the division of family responsibilities and the availability of suitable child care. It is also likely that a role is played by formal or informal historical practices involving the payment to women of a fixed percentage of the equivalent rate for men. Over time these differential payments may have influenced informal 
assumptions about the actual value of women's skills. Such assumptions would then be reinforced by the continuing division of labour and by provisions in legislation or collective agreements restricting women's access to certain areas of employment. In addition, women receive less overtime, are more likely to withdraw from the workforce and return to it at a later time with reduced status, and to present lower or otherwise restricted qualifications.

The discrepancy between men's and women's pay can also be referred to women's structural position in the workforce, that is, to industrial and occupational segregation. As OECD studies have indicated, there are problems inherent in comparing occupational segregation and associated rates of pay across countries. These problems follow from varying occupational categories, varying definitions of common categories, and varying measures of rates of pay. However, OECD data can be said clearly to exhibit analogous patterns of occupational segregation: Table 1 (2) provides a series of indices of the employment distribution of men and women by occupational groups.

The effect of occupational segregation on women's employment experience is receiving increasing attention in number of quarters. In a recent study in the United States which distinguished 238 occupational groups, it was estimated that if all women and men were paid the median earnings for their occupation, average female earnings would be 84.2 per cent rather than 100 per cent of average male earnings, because female employment is concentrated in lower-paid occupations (3). Comparison of female/male pay ratios for manual workers in manufacturing across a number of $O E C D$ countries indicates that women receive considerably less than men for work within a broad industry sector (see Table 2).

For the purposes of the present discussion, where appropriate earnings data are available, it appears to be the case that:

- women in women's occupations earn significantly less than men in men's occupations;

- - women in men's occupations earn significantly less than men in men's occupations; and

-. there is considerable variety between pay ratios across occupations regardless of the conventional occupants of those occupations.

This last point is of interest in that it indicates that pay differentials are not simply linked to some generalisable factor such as human capital, but vary according to internal features of occupational wage-setting mechanisms. Other reasons for earnings differentials which are often advanced include the importance of higher unionisation and militancy among traditional male occupations; the fact that women's skills have historically been informally taught, or learned at home, and have for this reason not received appropriate recognition in terms of curriculum development or formal accreditation; and the likelihood that job assessment schemes used in making comparisons between sex-segregated occupations are to varying degrees not free of sex bias and accordingly perpetuate differentials. 
National responses to the problem of pay inequity. must therefore address a number of structural features of the national wage-fixing system if they are to produce any significant effects. These include redressing the historical discrimination in the setting of women's wages (the family wage), the problem of setting equivalent wages across segregated occupations, and the role of legislation and arbitration in relatively centralised or decentralised bargaining systems. In some countries this process of adjustment is taking place on the ground as courts or tribunals continue to interpret existing legislation in response to particular claims. In others, systematic legislative attempts are being made to address wage-based discrimination. In some relatively centralised systems, action has been taken through the wage-fixing mechanism to raise earnings for lower paid workers.

There is a number of practical links between historical wage-fixing systems and the role of industrial action for pay equity and actual movements in the ratio of women's to men's earnings. These create a context for the various national approaches to pay equity and raise issues associated with the. definition and accreditation of skills.

\section{THE FAMILY WAGE}

Embedded in the economic histories of a number of industrialised countries considered in this paper is the practice of basing union-employer wage negotiations on the assumption of a male-headed family. Often this seems to have meant that where women were in male occupations and may have competed with men they were to be given equal pay, while women in traditionally female occupations received a proportion of the male wage. Thus a set of social assumptions having nothing to do with the value of work to an employer were instrumental in establishing pay relativities which have often survived the setting of a single minimum adult wage. These relativities have recently become issues in work value claims in both industrial and legislative contexts.

\section{Australia and New Zealand}

In the 1907 Harvester Case, heard at the then Australian Commonwealth Court of Conciliation and Arbitration in 1907, Mr Justice Higgins was required to set a "fair and reasonable" level of pay for an unskilled worker. Rather than looking solely to the value of that labourer's work to an employer, he took into account "the normal needs of the average employee, regarded as a human being living in a civilised community" (4). These normal needs were taken to include a wife and three children, and the "family wage" was set accordingly. Margins were added to this basic wage for skilled workers.

No mention was made of a female rate in the Harvester decision. However, in 1912 during the Rural Workers (or Fruit Pickers) case women's rates were explicitly raised as an issue, and two principles were established that became precedents for the Arbitration Court. 'First. equal pay was to be 
given to women and men in cases in which cheaper female labour would be likely to displace male labour. And secondly, where sex-segregated occupations were in question, women were to receive a percentage of the rate paid to men. It was assumed also that there are inherent differences between the sexes which make some occupations 'naturally' more suitable for women than for men.

In 1919 the basic wage for women was set at 54 per cent of men's basic wage.

In the similarly centralised New Zealand system the National Arbitration Court:s argument for higher rates of pay for men was also founded on the concept of the family wage. "The material requisites of normal life, for the average adult male includes provision for his family; in other words, his decent livelihood means a family livelihood ... Therefore the adult male labourer has a right to a family living wage." (5) On this basis the Court decided on differential reductions in wages following a fall in the cost of living in 1922, and introduced in 1936 the first minimum adult wages, with women receiving 47 per cent of the male minimum.

\section{Canada}

In Canada, a pattern similar to that in Australia began to appear after the entry of women into the workforce in 1917, when the introduction of conscription led to massive labour shortages. The resulting contribution of women to the paid workforce was officially recognised in mid-1918 when the Canadian government announced its endorsement of seventeen principles and policies to be used in governing the relations between employers and workers. The three most influential principles were the living wage, the minimum wage and equal pay, or the view "that women on work ordinarily performed by men should be allowed equal pay for equal work and should not be allotted tasks disproportionate to their strength" (6).

In Canada, too, minimum rates of pay were based on a cost-of-living budget for a single woman or "the least sum upon which a working woman can be expected to support herself", while the living wage or male rate was calculated as being sufficient for the maintenance of a family, that is, a breadwinner, wife and 2 or 3 children. This kind of differential calculation led to the habit of setting women's wages at a level of about two-thirds the amount set for men.

On June 28, 1919 a Royal Commission commended the enactment of minimum wage legislation: By that time, five provinces already had female minimum wage laws in place and two more were enacted within the year. The legislation was limited to women workers in factories, shops, offices, hotels, restaurants, and places of amusement.

\section{Great Britain}

Despite the less centralised system in Great Britain the concept of the family wage undoubtedly affected the setting of wages there for men and women prior to the coming into force of the Equal Pay Act in 1975. Differential 
rates of pay were still widely acceptable at the turn of the century even though a move towards. equal pay was called for by the British Trades Union Congress as early as 1888 .

\section{Denmark and Sweden}

In Denmark, the Public Servants Act of 1919 abolished direct differences in the salaries of male and female public servants. However, a special allowance was introduced for persons with dependants and a concept of head of household was introduced which effectively benefited married men. This special system was abolished in 1958 .

In Sweden the general wage differences between female and male workers up to the 1960 s were partly based upon the assumption that a man had a family to support. Here too a special family addition, negotiated in the same way as wages, was paid to male "breadwinners" in certain occupations up to the beginning of the 1960s. The "family addition", however, was never of any great economic importance.

\section{United States}

In the United States, the family wage concept was never officially recognised by Government, nor were differential rates ever set by law. However, in the private sector it was common for many employers to assume that men needed to provide for a family so that, prior to the introduction of minimum wage legislation, it was common for men to be paid more for the same job than women, and occupations held predominantly by women were low in pay. During the time when it was legal to segregate jobs, it was also possible for the most skilled "woman's job" to be paid less than the least skilled "man's job".

Generally the United States government has not involved itself in setting wages for employment in the private sector, except that there has been a federal minimum wage since 1938. Also. most of the States have a minimum wage. The minimum wage (federal or State) is the same for men and women regardless of marital status or dependants.

\section{Qther Countries}

Similarly, no formalised concept of the family wage was reported by other participating countries. However, Portugal reported that women have always been affected by a traditional view that men are "family chiefs." It has followed from this view that in Portugal men's wages have been regarded as a basic family support and women's wages as only complementary. In the 1978 Civil Code, however, the rights and situation of each spouse are clearly distinguished. Turkey reported that no differences existed between men's and women's pay before the law in Turkey since the reforms of Ataturk. 
All of the countries taking part in the study have some form of legislation relating to pay equity, often as a response to international commitments made to the ILO or EEC. The major issues running through such provision are:

- The extent to which it extends beyond identical or similar work to dissimilar work of equal value, and the measures which it puts in place for establishing the equal value of dissimilar work:

- The extent to which it requires a complainant in order to be triggered or alternatively incorporates proactive measures, such as inspectorates or mandatory reporting requirements; and

- The extent to which it covers non-wage remuneration such as allowances and pensions.

In a number of countries, such as Australia, Belgium and the Scandinavian countries, however, pay equity has been largely addressed by collective agreements and industrial tribunals. One clear ground for this difference of approach has been the comparatively centralised nature of the national wage-fixing systems of those countries in which legislation plays a comparatively minor role. Alternatively, Great Britain, Canada and the United States, which have, in that order, increasingly decentralised systems, have tended until recently to look to legislation to address pay equity matters.

Most countries, regardless of the nature of their wage-fixing systems, have undertaken equal employment opportunity and anti-discrimination measures aimed at breaking down the occupational and vertical segregation of women in the labour market.

\section{Equal Pay Legislation}

The significant increase in women's workforce participation during and after World War II, together with the attention directed to the issue by women's groups, led to considerable international debate on the merits of equal pay.

The ILO had begun developing an equal remuneration standard in 1948 . and this was adopted in 1951 as ILO 100. ILO 100 defines "remuneration" as including "the ordinary, the basic or minimum wage or salary and any additional emoluments whatsoever payable directly or indirectly, whether in cash or in kind, by the employer to the worker". The Convention calls for the application of the principle of equal pay for.work of equal value through national laws or regulations, recognised wage determination machinery; collective agreements or a combination of these. It allows for the "objective appraisal of jobs" where such a process will assist in giving effect to the provisions of the Convention. 
Since ILO 100 was first ratified, the scope and definition of "equal value" have become issues for debate. Until the 1970s, the Convention was narrowly interpreted to mean equal pay for equal (identical or very similar) work. In effect this meant that the lower wages usually given to women could not become a means to displace male workers.

Six years after ILO 100 was adopted equal pay for equal work was included as Article 119 of the Treaty establishing the European Economic Community. Again, there was uncertainty concerning the scope and definition of equal work. As a result, in 1975, the EEC issued Directive No. 117, in which the principle of equal pay was required for "the same work or for work to which equal value is attributed". The Directive called for job classification systems free from gender bias and required Member states to "introduce into their national legal systems such measures as are necessary to enable all employees who consider themselves wronged by failure to apply the principle of equal pay to pursue their claims by judicial process after possible recourse to other competent authorities".

Both ILO and EEC commitments have had an impact on national activity for equal pay. Most commonly this has taken the form of legislation and legislative review.

\section{Great.Britain}

The principle of equal pay was first put into practice in Great Britain in the civil service. In 1951 the Government agreed to grant equal pay to non-industrial civil servants in a staged process spanning 1955-1961.

Private sector equal pay legislation was first introduced on 29 December 1975 when the Equal Pay Act 1970 (amended by the Sex Discrimination Act 1975) took effect. This Act provided that all men and women doing the same or broadly similar work for the same or an associated employer are entitled to equal pay and equal terms and conditions of employment unless the employer could show that the difference in pay was genuinely due to a material difference other than the difference of sex between the women's case and the man's. It also provided that collective agreements or pay structures containing rates applying specifically to women could be referred to the Central Arbitration Committee in order that those rates could be brought up to the lowest male rate in the agreement or structure. This latter provision was repealed in February 1987.

The Equal Pay Act was amended on 1 January 1984 by the Equal Pay Amendment Regulations 1983 to extend work value comparisons from work which was "like" or had already been "rated as equivalent" to include work of "equal value" in terms of the demands made under such headings as effort, skill and responsibility. This action was taken in order to bring British legislation into full compliance with the European Equal Pay Directive following a ruling of the European Court of Justice in 1982 that existing legislation did not contain measures to enable employees to obtain equal pay for equal work where there was no like work or system of job classification. Claims under the present legislation are brought by individual women through their unions to 
industrial tribunals. Class actions are not possible. The Advisory Conciliation and Arbitration Service has a statutory duty to attempt conciliation in complaints by individuals against employers made to industrial tribunals under the Act.

\section{Canada}

Within the span of eight years after the adoption of ILO 100, eight Canadian jurisdictions had passed equal pay laws; these in turn were affected by the ratification in 1964 of Convention 111 concerning Discrimination in Respect of Employment and Occupation. In 1975, the Bill which would ultimately establish the Canadian Human Rights Act was introduced. Section 11 of the Act, which came into force on March 1, 1978, states that it is a discriminatory practice for an employer to establish or maintain differences in compensation between male and female employees in the same establishment who are performing work of equal value based on the standard criteria of skill, effort, responsibility, and working conditions. It covers all federally regulated sectors including the federal public service, Crown corporations, and those employed in banks, airlines, and interprovincial transportation. The Human Rights Commission can initiate complaints and respond to complaints brought by individuals, third parties such as labour inspectors or groups.

Provincial equal pay legislation applies to that proportion of the labour force working within its boundaries that does not fall within federal jurisdiction. Federal and provincial equal pay legislation between them cover about one third of the Canadian workforce.

The scope of provincial Canadian legislation varies between jurisdictions. Every province has legislation mandating equal pay for similar and substantially similar work. Quebec, Yukon's public sector and the federal jurisdiction require equal pay for work of equal value. Manitoba's public sector has moved on to a regulatory model which "does not simply prohibit wage discrimination but places positive obligations on employers to scrutinise their pay principles and ensure that these practices comply with the legislation" (7). Ontario's Pay Equity. Act provides analogous coverage in both the public and private sectors. Prince Edward Island and Nova Scotia recently enacted pay equity legislation covering public sector employers. Newfoundland took a non-legalised approach and signed a memorandum of agreement with its unions to study and implement pay equity.

In addition to the complaints and enforcement mechanisms of the Canadian Human Rights Act, Section 182(2) of the Canada Labour Code enables an inspector to notify or file a complaint with the Canadian Human Rights Commission where the inspector has reasonable grounds to believe that the equal pay provisions of the Canadian Human Rights Act have been breached.

Labour Canada's Equal Pay Program was established in 1984. Its aim is to eliminate sex-based wage discrimination in the federal jurisdiction. The program has identified a three-step process in order to determine compliance and to respond to non-compliance. The first step is an educational visit to 
inform employers of their legal obligations and to provide advice. The second step is a series of monitoring visits to these same employers to answer technical questions and to verify progress. The final step is on-site inspection and subsequent referral to the Canadian Human Rights Commission if non-compliance is found. The program also undertakes numerous educational and promotional activities such as speeches, seminars, and publications. It promotes industry-wide pay equity initiatives by employer associations whose member companies lack the sophistication or size to implement equal pay on their own.

\section{United States}

The Equal Pay Act 1963 provides in the federal jurisdiction for equal pay for jobs whose performance requires equal skill, effort and responsibility, and which are performed under similar working conditions. The Act protects most private employees whose employers are covered by the Fair Labor Standards Act, including executive, administrative, professional and outside sales employees who are exempt from the minimum wage and overtime provisions. Most federal, state and local government workers also are covered under the Act. While this provision is generally held to be applicable only to jobs "substantially equal" in nature, a number of American states have adopted laws that go beyond equal pay for equal work and call for equal pay for work of comparable worth.

Most individual states already have equal pay laws or fair employment laws comparable to the Equal Pay Act or Title VII (see below) or both. According to a recent survey conducted by the Council of State Governments, many states are giving serious attention to the issue of pay equity. California, Iowa, Minnesota, Oregon and Washington are taking active steps to equalise pay levels between jobs held predominantly by women and comparable jobs held predominantly by men.

Approaches at the federal level to widening the scope of comparison permissible under the Equal Pay Act have been made on the basis of Title VII of the 1964 Civil Rights Act (42 United States Code Section 2000e-2(a)), which makes it an unlawful employment practice for an employer i) "to discriminate against any individual with respect to his compensation terms, conditions or privileges of employment, because of such individual's sex;" or ii) "to limit, segregate or classify his employees ... in any way which would deprive or tend to deprive any individual of employment opportunities or otherwise adversely affect his status as an employee" because, inter alia, of such a person's sex. Title VII coverage extends to federal government employees, private employers, state and local governments, educational institutions and labour organisations having. 15 or more employees. Although a reference to wage differentiation authorised by the Equal Pay Act was incorporated into Title VII of the Civil Rights Act through the Bennett Amendment, court practice entertains claims under Title VII going beyond a comparison of "substantially equal" jobs in the same establishment without, however, theoretically endorsing the comparison of different jobs through common evaluation criteria (8). Instead, courts have tended to rely on a finding of intentional discrimination where a job evaluation study has been delayed or disregarded by the employer. 
In 1985, the US Equal Opportunity Commission issued a decision (85-8) describing the evidence which it believed proved a claim of sex-based wage discrimination under Title VII. The Commission held that such claims might be proved by:

- evidence of the discriminatory application of a wage policy or system or the discriminatory use of wage-setting techniques such as job evaluations or market surveys;

$\therefore$ evidence of barriers to equal access to jobs; or

- a preponderance of direct or circumstantial evidence that wages are intentionally depressed because of the sex of occupants of the job.

The control exercised by the federal jurisdiction over wage-setting by employers is extended by Executive Order 11246 of 1965, which requires that every non-exempt contract with the Federal Government contain clauses that impose upon contractors and sub-contractors anti-discrimination, equal employment and affirmative action obligations and require co-operation in reporting activities and investigations related to enforcement. The written affirmative action plans required of larger employers with federal contracts or sub-contracts involved a comprehensive requirement for self analysis of all positions, classifications, compensation, and also recruitment, training \& promotion patterns. When a compliance review identifies problems in the analysis, agreements must be reached to remedy them.

\section{Australia}

New South Wales was first to change its Industrial Arbitration Act to entrench the principle of equal pay for equal work in 1958, followed by Queensland in 1964, Tasmania (for public servants only) in 1966, South Australia in 1967, and. Western Australia in 1968. Victoria did not specifically introduce any equal pay legislation before 1969.

The establishment of a standard adult minimum wage in 1974 and the extension of equal pay for work of equal value to Australian women workers were industrially determined, and are considered separately.

In 1984 Australia passed its Sex Discrimination Act, which is administered by the Human Rights and Equal Opportunities Commission. There is no formal definition of equal pay in the Sex Discrimination Act; instead, it prohibits discriminatory terms and conditions of employment.

Four Australian States have equal opportunity legislation.

\section{New Zealand}

New Zealand has a centralised wage-fixing system, and equal pay legislation applying to both private sector and public sector employees. The Government Service Equal Pay Act came into force on 1 April 1961 and provided 
for the elimination of differences based on sex in scales of salary or wages paid to Government employees as soon as practicable after 1 April 1963. The Equal Pay Act 1972 implemented the principle of equal pay in the private sector. It provided for the removal and prevention of discrimination based on sex in the rates of remuneration of males and females in paid employment by five steps, and full implementation of equal pay by 1 April 1977 . It required the parties to a wage setting instrument to undertake a work classification exercise and determine rates of remuneration that represent equal pay in accordance with defined criteria rewarding skill, responsibility and service.

The Equal Pay Act 1972 defines remuneration as salary or wages actually and legally payable to an employee, including allowances, fees, overtime and bonus payments. Equal pay is defined as an equal rate of remuneration for female and male employees for any work or class of work, payable under any instrument, which calls for the same or substantially similar degrees of skil1. effort and responsibility and is performed under the same or substantially similar conditions. The Act applies to all rates of remuneration, including those paid for work which is exclusively or predominantly performed by female employees. In such cases equal pay would be implemented by determining a 'notional' male rate, that is, the rate which would be paid to male employees with the same or substantially similar skills, responsibility and service', performing the work under the same, or substantially similar, conditions and with the same, or substantially similar, degrees of effort.

\section{Portugal}

According to the Portuguese Constitution of 1976, men and women are equal in all aspects of social life and particularly in what concerns employment and remuneration. Article 60 of the Constitution states that "all workers without any distinction of sex are entitled to retribution of labour, according to quantity, nature and quality, thus observing the principle of equal pay for equal work, in order to ensure a decent living".

In 1979, Legislative Decree No. $392 / 79$ extended those Constitutional principles by requiring in Section 9 that "equal pay for working men and women for equal work or work of equal value done for the same employer, is ensured". Equal work is defined as work done for the same employer involving tasks which are alike or of a nature objectively equal. Work of equal value is defined as the work done for the same employer involving tasks which, though of a different nature, are considered equivalent after being evaluated on objective criteria. The legislation provides that job descriptions and job evaluations shall be based on objective criteria common to the two sexes. It does not cover work at home and domestic service, the state services and local authorities. However, Legislative Decree No. $426 / 88$ deals with the ways in which equal pay and equal treatment should be implemented in central, regional and local administration.

Under Section 12 of the decree, provisions in individual or collective agreements which are contrary to the principle of equal pay are deemed to be null and void. The legislation further provides that a lower (female) rate of 
remuneration prescribed in a contract or agreement shall be replaced automatically by the higher (male) rate. Under Section 17 penalties are prescribed for breach of Equal Remuneration Provisions.

A Tripartite Commission on Equality in Work and Employment was set up under the legislation with responsibility to inform the public, to advise the Government and to examine complaints regarding discrimination. The Commission advises on provisions in legislation and collective agreements which bear on pay equity. It also provides opinions on the existence of discriminatory situations or practices to the Portuguese Labour. Inspectorate, which under Section 18 has responsibility for enforcement of Legislative Decree 392/79. Finally, it supports research in the area.

\section{$\underline{\text { Japan }}$}

Article 14, paragraph 1, of the Japanese Constitution of 1946 proclaims the equality of all under the law and condemns any form of discrimination, particularly for reasons of sex, in any field of activity. Article 27, paragraph 2, provides for the statutory regulation of wages, hours of work and rest periods. Section 4 of the Labour Standards Act of 1947 repeats the constitutional prohibition of discrimination based on sex with reference to wages in general, whatever they may be called, as including all payments made by an employer to an employee in return for work. Section 119 of the Act provides for penal measures in cases of non-compliance.

With regard to public services, Section 62, paragraph 1 , of the National Public Services Act and Section 24, paragraph 1, of the Local Public Services Act stipulate that staff salaries must be based on the duties performed and the responsibility carried. Salary scales in these services are based on a standardised job classification system related to the difficulty of the work and the degree of responsibility. Section 27 of the former Act and Section 13 of the latter further forbid any discrimination for reasons of sex in the application of their provisions.

Application of the Labour Standards Act is the responsibility of the central office of the Ministry of Labour and of the prefectural offices to which the labour inspectors are attached. These inspectors have wide powers of investigation and, in the event of the discovery of an infringement. the authority of officers of the law. In implementing and adopting the Labour Standards Act, the Ministry of Labour and the Departmental labour authorities are assisted by a Labour Standards Council and Prefectural Labour Standards Councils respectively. These Councils serve in an advisory capacity and are tripartite in composition, involving employers, workers and representatives of the public interest.

The continuance, in spite of the 1947 legislation, of practices such as forced female retirement on marriage and segregation of the workforce (enforced by separate recruitment and promotion arrangements). resulted in the Law Concerning the Promotion of Equal Opportunity and Treatment between Men and Women in Employment and Other Welfare Measures for Women Workers, which became operative on 1 April 1986. The law prohibits sex discrimination in 
education and training, fringe benefits, hiring, placement, promotion, retirement and dismissal. Like the earlier legislation, it does not make provision for job evaluation methods for segregated occupations. There are no criminal penalties for an employer who does not comply with the law. It does however provide that an Equal Employment Opportunity Mediation Commission will be able to offer mediation of grievances autonomously.

\section{Greece}

Greece is bound by Article 119 of The Treaty of Rome and the Equal Pay Directive of 10 February 1975. In addition, the Greek Constitution of 1975 specifies that work of equal value should receive equal payment. Law 1414/84 on the Application of the principle of equality of the sexes in working relations sets out in Article 4 a requirement that men and women receive equal remuneration for work of equal value. Remuneration is defined as salary and any additional income which is paid by the employer to the worker directly or indirectly in the form of money or of sundries given in exchange for work undertaken. Article 12 provides sanctions for violators.

\section{Belgium}

In Belgium the Equal Pay Directive was implemented by Convention Collective du Travail (C.C.T. - Collective Labour Agreement) No. 25, approved by the Conseil National du Travail (National Labour Board) on 15 December 1975. enforced by Royal Order of 9 October 1975 and hence binding on all private sector employers in respect of all their workers. In the public sector, equality of pay between men and women already followed from Article 6 of the Constitution guaranteeing the equality of all citizens at law, as well as from Article 6bis proscribing all discrimination.

Subsequently, the Council of the European Communities adopted Directive No. $76 / 207$ of 9 February 1976 on equal treatment of men and women, particularly with respect to working conditions. This Directive is directly binding on the Belgian government. To implement this Directive. Title V of the Economic Reorientation Act of 4 August 1978 was adopted. Article 128 of this Act defines the "working conditions" in regard to which equality between male and female workers is incumbent on all employees and makes particular mention of pay. As a result, equal pay between men and women is now considered to have been achieved for:

-. all workers: under Article 119 of the Treaty of Rome;

- all private sector workers: under C.C.T No. 25 and Article 128 of the Act of 4 August 1978; and

- all public sector workers: under Articles 6 and $6 \mathrm{bis}$ of the Constitution and Article 128 of the Act of 4 August 1978.

C.C.T. No. 25 is based on a fairly broad definition of pay. However, in the case of "non-statutory social security benefits" (i.e. benefits that, by agreement or employer's decision, are additional to those provided under the 
statutory system), the C.C.T. deferred its entry into effect until the European Communities had issued a Directive. This was a rather restrictive view, inasmuch as the benefits could be deemed to be part of pay as defined in Article 119 of the Treaty of Rome, as the European Court of Justice has held (see for example the ruling in the Garland Case (12/81) of 9 February 1982). In any event, on 24 July 1986 the Communities adopted Directive $86 / 378$ on equality in occupational social security schemes. As a result C.C.T. No. 25 became applicable to the benefits under such schemes.

\section{Denmark}

There is a very strong tradition in Danish labour law that the formation of rules of law is entrusted firstly to the parties of the labour market themselves to be accomplished through the conclusion of collective agreements, and secondly to the Labour Court and the Arbitration Courts through the forming of legal usage. When in exceptional cases rules have been created by legislation, it has been to protect certain groups of wage earners whose organisations have had insufficient strength to protect their members. However in such situations legislation has usually been founded upon the content of the collective agreements of the labour market. In the case of pay equity. legislation implementing Article 119 of the EEC Treaty in 1979 followed a settlement in 1971 and 1973 which had already had the effect of narrowing the pay gap between the basic wages of women and men.

The Danish Equal Pay (Consolidation) Act No. 237 of 5 May 1986 gives the following definition of equal pay in Section 1:

1. -. (1) No discrimination in terms of pay on the grounds of a person's sex may take place in contravention of the provisions laid down in this Act.

- (2) Any employer who employs men and women shall give them equal pay, including equal pay terms, for the same work or work given the same value.

- (3) This Act shall not be applicable in cases where a similar duty concerning equal pay follows from a collective agreement.

2. An employee whose pay in contravention of section 1 is lower than the pay of others shall be entitled to claim the difference.

\section{Sweden}

The principle of equal remuneration, irrespective of sex, for identical appointments, was first introduced in the public sector in Sweden in 1947. In 1960 the Swedish Trade Union Confederation and the Swedish Employers' Confederation agreed on the abolition of specifically women's wages over a five-year period. It was agreed that women and men should be paid the same for equivalent work. Collective agreements on equality began to extend across the labour market. In 1961 ILO convention No. 100 was ratified. 
In terms of legislation the question of equal pay is addressed in the Swedish Act on Equality between men and Women at Work (1980), which prohibits discrimination on the grounds of sex. The Act provides in Section 4 that:

"Discrimination on the grounds of sex shall also be considered to exist where an employer:

1. applies to an employee less favourable terms of employment than those applied by that employer to an employee of the opposite sex where the work they perform is to be regarded as equal on the basis of collective agreement or established practice within the branch of activity, or as equivalent according to an agreed job evaluation. unless the employer can show that the discrepancy in the terms of employment is not due to the employee's sex."

The Act covers the public sector as well as the private sector as regards the prohibition of discrimination. It also has provisions which make it incumbent on an employer to take active steps to promote equality. This part of the law can be set aside by collective agreements to the same effect.

The term "equal pay" is not mentioned in the Act on Equality between Men and Women at Work, which uses the wider concept 'equal terms of employment' in its Section 4. It is also stated in Section 5 of the law that "any contract or agreement providing for different treatment of women and men in respect of terms of employment or in any other way permitting discrimination on the grounds of sex within the meanings of sections 3 and 4 shall be null and void".

\section{Finland}

Legislation addressing pay equity came into force in Finland on 1 January 1987 as part of a broader package of equity legislation and covers both the private and the public sectors. The Equality Act specifies (Section 8) that the actions of an employer shall be regarded as discriminatory if (inter alia) the employer "applies to an employee conditions of payment or employment less favourable than those he applies to an employee of the opposite sex employed by him in the same work or work of equal value". The concept of work of equal value has not been specified in the Act; nor has 'conditions of payment' been further defined. An employer who is found to have violated the prohibition on discrimination is liable to pay compensation.

\section{Turkey}

Equal pay legislation was first introduced in Turkey in 1967 through the Turkish Labour Act No. 931 and covers both public and private sector workers. The State Official's Law enacted in 1965 also includes the principle of equal pay. In addition, Article 55 of the 1982 Turkish Republic Constitution calls for. a "guarantee of fair wage" and stipulates that "the State shall take the necessary measures to ensure that workers earn a fair wage suitable for the work they perform and that they enjoy other social benefits." 
The Turkish Labour Act No. 1475 defines wages as "the amount of money to be paid in cash by an employer or third party to a person in return for work performed". It also specifies that "in an undertaking, no distinction shall be made on grounds of sex between the wages paid to male and female workers performing jobs of the same nature and working with equal efficiency [and that] no provision contrary to this principle may be included in any collective agreement or contract of employment".

Formal definitions of equal remuneration and comparable worth are set out in collective labour agreements.

\section{Definition of Work Value and Legislative Experience}

While there is a consensus among participating countries that there should be equal pay for similar work or for work of equal value, there is no consensus regarding whether work value is to be measured in terms of value to the employer (including market factors), demands on the employee, or by reference to a system of established work values - or more precisely, which of these three factors should predominate. Value to the employer/demands on the employee measurements tend to be associated with legislative processes, while established relativities are more likely to be cited in central wage fixation processes.

Value to the employer/demands on the employee approaches to work value are expressed in the definitions and methods of work value comparison established in the legislation. Where the emphasis is on demands on the employee, account is usually taken of the skill, effort, responsibility and working conditions involved. Where the emphasis is on value to the employer. attention is also paid to "market forces" and "reasonable factors" or "material differences" which may not be relevant to the work actualiy done but which justify wage differentials. Most legislation contains aspects of both versions of work value, and this has meant that case law may have a significant role to play in influencing judgements.

The evolution of case law in the countries under consideration has been dependent on a number of factors ranging from the difficulty of interpreting the legislation itself to the restrictions placed on the legislation by the national institutions which have responsibility for administering it. Thus while conventional courts may be institutionally unwilling to undertake work value exercises, arbitration courts may be unwilling to address matters involving discrimination.

In the material which follows only characteristic or influential decisions are considered; the discussion is by no means intended to be comprehensive. 


\section{Great Britain}

Under the amended Equal Pay Act 1970 a woman may claim equal pay:

-. when she is doing 'like work' to that of a man;

- when a woman's job and a man's job have been given an equal value under a proper job evaluation study, that is, an analytical scheme which assesses jobs under various headings such as skill, effort and responsibility. She may also have a claim if her job would have been rated as equivalent had the scheme not discriminated on the ground of sex;

- when her work is of equal value to that of man in terms of demands made on her.

The Equal Pay Act states that a job evaluation study will be regarded as discriminatory if it is based on a system which discriminates on the grounds of sex where a difference or coincidence between values set by that system on different demands under the same or different headings is not justifiable.

Even when a woman has shown "like work" or her job has been given an equal value under a proper job evaluation scheme, she will under present legislation have no right to equal pay if her employer can show that there is a material. difference (not based on sex) between the job-holders which justifies the pay gap.

Until 1986 case precedent had defined a material difference as a difference (other than a difference based on sex discrimination) between the "personal equation" of the woman and the man, meaning the things which they personally bring to a job, for example, a degree, a diploma or relevant experience (Fletcher $v$ Clay Cross (Quarry Services) Ltd, 1978, IRLR 361). However, in 1986 the House of Lords criticised the decision of the Court of Appeal in Fletcher as being too narrow in excluding factors outside the "personal equation". In their view, defences may be made out where the difference in pay is due to objectively justifiable grounds which can include both genuine economic grounds and administrative efficiency (Rainey v. Greater Glasgow Health Board, 1987, IRLR 26). This decision may extend the scope of the material difference defence to cover, for example, skills shortages.

The latest figures available indicate that in a 1986/87 12 month period 517 applications under the amended British Equal Pay Act were registered with industrial tribunals (which are independent judicial bodies set up to provide the means of dealing with disputes in the employment field) of which 282 were withdrawn, 44 were successful, 71 were conciliated settlements and 120 were dismissed or disposed of otherwise.

A number of cases have dealt with the matter of specifying comparators. The tribunals have found, for example, that comparisons cannot be made between employees of the same employer who work different hours (Leverton $v$ Clywd County Council: appealed, overruled) or who receive different remuneration packages (Hayward v. Cammel Laird Shipbuilders: appealed, upheld), or between 
an employee or her predecessor (Macarthys Ltd v. Smith: appealed, overruled) or between employees doing work of equal value but possessing different personal attributes (McGregor and others v. GMBATU). In a controversial decision the Employment Appeal Tribunal ruled that if sex-segregated occupations were not 100 per cent female, no equal pay claim could be brought (Pickstone and Others $v^{b}$ Ereeman: appealed and overruled, further appealed).

A further restriction put on comparators in the British legislation concerns the role in comparison of hypothetical as well as actual male workers. In Macarthys Ltd v. Smith (No. 2) (1980 3 ALL ER 111, CA) the Advocate General assigned to the case by the European Court of Justice considered that comparisons could include hypothetical male workers, thus providing a legal remedy for sex-based pay discrimination in sex-segregated occupations. However, the Court itself disagreed with the Advocate General's opinion on this point on the ground that the construct of a hypothetical male worker "implies comparative studies of entire branches of industry and therefore requires, as a prerequisite, the elaboration by the community and national legislative bodies of criteria of assessment".

In addition to these matters, a further issue of interest has arisen in relation to British legislation: the question of differences in remuneration flowing from previous discrimination. In the former case (Snoxell and Davies v. Vauxhaul1 Motors Ltd, 16 March 1977), a group of male workers had retained their higher rate of pay when job reorganisation had reduced the prescribed rate for the job. No woman was in this group because at the relevant time the grade was not open to women. The Employment Appeal Tribunal ruled that an employer can never establish that a variation between a man's and a woman's contract is genuinely due to a material difference other than the difference of sex when it can be seen that past discrimination has contributed to the variation.

\section{Canada}

In Canada the terms used by the Canadian Human Rights Act refer to work of equal value. Section 2(2) specifies the criteria for work value assessments, namely, a composite of the skill, effort and responsibility required in the performance of the work and the conditions under which the work is performed. Where an employer relies upon an existing system in assessing the value of work performed by employees employed in the same establishment, that system is to be used in the investigation of any complaints regarding wage differentials so long as it operates without any sexual bias; is capable of measuring the relative value of work of all jobs in the establishment; and assesses the skill, effort, responsibility and working conditions of the individual or occupational group concerned. An establishment is defined as all the employees of an employer subject to a common personnel and wages policy, whether or not such a policy is centrally administered. 
Comparators may be individuals or occupational groups in the same establishment as the complainant or the complainant's occupational group. An occupational group is defined as predominantly of a specified sex if that sex composes:

70 per cent of a group of less than 100;

60 per cent of a group of less than 500;

55 per cent of a group of more than 500;

"Reasonable factors" accepted under the Equal Wages Guidelines issued by the Human Rights Commission as justifying wage differentials include different performance ratings, a seniority system, the downgrading of a position, a rehabilitation assignment, a demotion procedure, a temporary training position. the existence of an internal labour shortage, the reclassification of a position and regional rates of pay.

The vast majority of cases filed with and settled by the Canadian Human Rights Commission have dealt with the Federal Public Service. The Public Service Alliance of Canada (PSAC), which has filed more than a dozen complaints, estimates that its five settled cases have resulted in upward salary adjustments for over 10000 employees and total settlement payouts of over $\$ 20$ million, plus continuing higher salaries.

The first major case involving dissimilar work to be settled successfully by the Commission was PSAC's February 1979 complaint that the 65 per cent female, 470 person Library Sciences Group was performing work of equal value to that of the 75 per cent male, 230 person Historical Research Group represented by the Professional Institute of the Public Service of Canada. Evaluations based on a representative sample of 30 positions from the Library Services Group and 25 positions form the Historical Group were performed by the union, the employer and the Commission using a universal job evaluation plan. A finding by the Commission, in October 1980, that there was discrimination led to the $\$ 2.3$ million settlement in December 1980.

A second case was PSAC's 1979 complaint on behalf of the 2300 women and 1000 men who were concentrated in the three lowest paid subgroups in the General Services Groups food ( 60 per cent female). laundry (52 per cent female) and miscellaneous personnel services ( 59 per cent female). The four mostly male subgroups (messenger, custodial, building, and store services) were on average paid substantially more. The seven subgroups were all paid at different rates. The Treasury Board acknowledged in May 1980 that they all performed work of equal value. Pay disparities ranged up to $\$ 1.50$ per hour between men and women doing work of equal value. A settlement was negotiated in March 1982 in which the three complainant groups were compensated for past discrimination, receiving a total of $\$ 17$ million, which covered average wage increases of $\$ 5000$ retroactive to November 1978. The second part of the settlement was the establishment of equal pay for work of equal value for all General Services groups. 
A new generation of complaints is now being filed using the anti-discrimination provisions of the federal Act. Sections 7 and 10 . These sections are used either alone or in combination with Section 2 to attempt to identify systemic discrimination in the federal public service classification system. One example is PSAC's 1984 complaint that the 55,000 members of the 80 per cent female Clerical and. Regulatory Group are performing work of a value equal to the 20000 members of the 67 per cent male Program Administration Group. The Clerical and Regulatory Group complaint followed up on a 1982 settlement in which PSAC, using Sections 7 and 10 successfully increased by $\$ 2200$ the salaries of 280 registered nursing assistants at federal hospitals. The nursing assistants had been given the same point ratings and salary as male orderlies even though they had significantly greater training and certification requirements (9). As a result of the 1984 complaint, the members of the Clerical and Regulatory Group received pay increases of diverse magnitude, together with back-payments.

\section{United States}

Methods of determining work value in relation to claims under Title VII of the Civil Rights Act have been dependent on a developing body of case law. The courts generally have focused on analysing employees as a group or class. A determination of whether employees are similarly situated in a claim citing disparate treatment generally involves a determination of whether: i) the employees share the primary or basic job function or duty: $i i)$ the jobs have a number of job elements in common; $i j i)$ the jobs involve relatively the same degree of responsibility, difficulty, and complexity; and iv) the employees in the lower paid jobs, departments, and classifications possess the same relative qualifications as the employees in the higher paid jobs, departments, or classifications. When all four requirements are met, the employees can be considered similarly situated, so that the rate of compensation should be the same regardless of whether the departments, classifications, or jobs are segregated.

In the case of a more broadly based 'pattern and practice' claim the charging party must ultimately prove that the employer engaged in pattern and practice of wage disparity for discriminatory reasons. The claimant is required to meet the initial burden of offering evidence adequate to establish a prima facie case of inference of discrimination. This can be accomplished by showing that the employees are similarly situated and by use of statistics showing wage disparity on the basis of race, colour, sex, religion, or national origin coupled with testimonial or other evidence showing related individual instances of discriminatory wage disparity.

Broadly speaking, the courts have followed County of Washington $v$ Gunther, 452 U.S. 16126 EPD in suggesting that there are no recognised and accepted standards for making assessments "under which plaintiffs might claim increased compensation on the basis of a comparison of the intrinsic worth or difficulty of their job with that of other jobs in the same organisation or community". Two recent cases have further extended the burdens on comparable worth plaintiffs by saying that work value comparisons are insufficient as a matter of law to make out a comparable worth case. Even if a plaintiff can 
show that a male-dominated job is paid more than a female-dominated job and that the two jobs are equal in skill, effort and responsibility, the plaintiff loses unless she can also show wilful discrimination by the employer. It is uncertain exactly what this means in terms of the evidence required to establish a case of pay discrimination. In American Federation of State, County and Municipal Employees (AFSCME) Washington, $770^{\circ}$ F 2d 1401 (9th Gr. 1985) the Court argued that:

Job evaluation studies and comparable worth statistics alone are insufficient to establish the requisite inference of discriminatory. motive critical to the disparate treatment theory.. . the weight to be accorded to . . . statistics is determined by the existence of independent corroborative evidence of discrimination.

In a later and supportive decision Federal Court of Appeal decision. Judge Richard Posner argued that:

Knowledge of a disparity is not the same thing as an interit to cause or maintain it; if for example the state's intention was to pay market wages, its knowledge that the consequence would be that men got higher wages on average than women and that the difference might exceed any premium attributable to a difference in relative worth would not make it guilty of intentionally discriminating against women. Similarly. even if the failure to act on the comparable worth study could be regarded as "reaffirming" the state's commitment to pay market wages, this would not be enough to demonstrate discriminatory purpose. To demonstrate such a purpose the failure to act would be motivated at least in part by a desire to benefit men at the expense of women. (American Nurses Association v. State of Illinois, 783 F. 2d 71617 th GR, 1986).

In addition, some courts have suggested that employers could rely on conditions in the market place such as market wage, supply and demand, and collective bargaining ability in establishing wage rates [see Lemons $v$. City and County of Denver, 620 F. 2d 22822 ERD 30, 852 (10th Cir. 1980) CERT. DEN. US 888, $101 \mathrm{~S} . C T .24,24$ EPD 31,256 (1980) Christensen v State of Iowa, F $2 d$ 353 (8th Cir. 1977) and Briggs $v$ City of Madison 536 F. Supp 435, 29 EPD 32, 721 (W.D. Wis. 1982)]. In Lemons, a community wage scale that in part recognised economic balance and relationships prevailing in the community was used to set wages. The Lemons Court, as well as the Christensen and Briggs courts, also mentioned as factors used in setting wages the existence of past attitudes and practices of paying females less than males on the grounds of stereotyped notions such as the view that males are the family breadwinners. In Lemons, the court noted that the employer used a community-wide wage scale in an attempt to place its workers on a pay parity with other employees in the community.

In Briggs and Christensen, worth of jobs to the employer was partially determined by use of a job evaluation study. The employers then deviated from or modified the results of the internal studies to make adjustments reflecting external marketplace wages. This practice was accepted by the Court as providing no direct proof of intentional discrimination. The Court in Briggs 
found that "... under Title VII, an employer's liability extends only to its own acts of discrimination. Nothing in the Act indicates that the employer's liability extends to conditions of the marketplace".

The United States Equal Pay Act was initially enforced by the Department of Labor, and now both the Equal Pay Act and Title VII of the Civil Rights Act are enforced by the Equal Employment Opportunity Commission (EEOC). While the EEOC has the power to sue employers under both pieces of legislation, it has never filed a comparable worth suit. Equal pay complaints can be filed under either provision or both. For example, in 1983, 1659 cases were filed under the two acts simultaneously. Cases can be closed by negotiated settlements. conciliations, and court cases. In 1983, under the Equal Pay Act alone 2431 people were awarded a total of $\$ 3138000$ in settlements. Cases have also been brought under state equal pay and fair employment practice or human rights statutes.

\section{Australia}

Thus far in Australia pay equity has been treated as an industrial matter and accordingly addressed within the Commonwealth Conciliation and Arbitration Commission (now the Industrial Relations Commission). No equal pay cases have been brought under Australian federal or state legislation.

The process of establishing work value in Australia began in the 1949-50 National Wage Case, in which there was considerable discussion of equal pay for equal work. In the event, women's wages were raised then from 54 per cent to 75 per cent of the male rate. Then in 1969, the ACTU (Australian Council of Trade Unions) lodged a claim for 'equal pay for equal work' before the Conciliation and Arbitration Commission (now the Industrial Relations Commission).

In its judgement on the ACTU claim, the Commission accepted the concept of 'equal pay for equal work' and set down nine principles to deal with its implementation. In effect these principles limited the application of the decision by providing that only women who were performing identical work under the same award or determination as male workers would receive equal pay. Statistically, this meant that only about 18 per cent of women workers benefited from the decision.

In 1972 the unions and various women's organisations went back to the Conciliation and Arbitration Commission. They pointed to the restricted application of the equal pay principle under the 1969 decision and asked for an extension of that principle along the lines established by ILO 100 . In its response the Commission endorsed:

the concept of "equal pay for work of equal value". This means that award rates for all work should be considered without regard to the sex of the employee" (10).

In practice, this meant to the Commission that: 
Implementation of the new principle by arbitration will call for the exercise of the broad judgement which has characterised work value inquiries. Different criteria will continue to apply from case to case and may vary from one class of work to another. However, work value inquiries which are concerned with comparisons of work and fixation of award rates irrespective of the sex of employees may encounter unfamiliar issues.

Work value comparisons should, where possible, be made between female and male classifications within the award under consideration.

But where such comparisons are unavailable or inconclusive, as may be the case where the work is performed exclusively by females, it may be necessary to take into account comparisons of work value between female classifications within the award and/or comparisons of work value between female classifications in different awards. In some cases comparisons with male classifications in other awards may be necessary.

The value of the work refers to worth in terms of award wage or salary fixation, not worth to the employer (11).

The suggestion that comparisons of work value might be made between female and male classifications was never followed.

Historically, it has been argued, both Australian employers and Australian unions have resisted systematic or fully analytical methods of work valuation and comparison, as they might upset established wage relativities: and these are precisely the sorts of exercises which work value comparisons in a sex segregated workforce have been found to involve. In practice after the 1972 decision new classifications were introduced into awards and relativities by consent and negotiation, a process which could be argued in many cases to have had the effect of entrenching historical inequities. Alternatively work value comparisons were made at the task level rather than at the more general level where dissimilar jobs can be compared.

In 1985, the ACTU lodged a test case on the issue of "equal pay for work of equal value". In its 1986 decision the Commission readily re-affirmed the 1972 Equal Pay Principles but rejected the term "comparable worth" as being "inappropriate and confusing". It was felt that the concept of comparable worth allowed too broad a view of work value comparisons and thus would "strike at the heart of accepted methods of wage fixation in this country and would be particularly destructive of the present Wage Fixing Principles". In order to protect the current wage fixing principles and still allow the 1972 Equal Pay Principles to be applied, the Commission decided that any claim for Equal Pay should be processed under the Anomalies Provision of the wage fixing principles.

The 1986 decision restricted the application of the 1972 decision. In the first place, the Commission did not address the question of readjusting those awards in which a case could be made that equal pay had been incorrectly or only partially implemented; and in the second place it defined equal pay claims as anomalies rather than straightforward matters of work value. This 
means that by definition overriding considerations in any decision are that "there must be no likelihood of flow-on" and that "the economic cost must be negligible". Both of these limitations had the effect of safeguarding existing pay relativities.

\section{New Zealand}

Section 3 of the 1972 New Zealand Equal Pay Act sets out the criteria to be observed in making equal pay determinations:

a) For work which is not exclusively or predominantly performed by female employees:

i) The extent to which the work or class of work calls for the same, or substantially similar, degrees of skill, effort, and responsibility; and

ii) The extent to which the conditions under which the work is to be performed are the same or substantially similar:

b) For work which is exclusively or predominantly performed by female employees, the rate of remuneration that would be paid to male employees with the same or substantially similar, skills, responsibility, and service performing the work under the same, or substantially similar, conditions and with the same, or substantially similar, degrees of effort.

In addition, Section $3(2)$ requires that no account be taken of any statutory limitation on the work which women might perform when setting equal pay rates, while Section 3(3) required the removal by 1 April 1977 of any classification that differentiated on the basis of sex in the work which males and females could perform.

The Equal Pay Act gave the New Zealand Arbitration Court wide powers for overseeing the implementation process, for interpreting the Act and for providing guidance for unions and employers. Unfortunately, as the committee appointed by the Minister of Labour to review implementation of the Act noted. the Arbitration Court never exercised its power under Section 9 "to state, for the guidance of the parties in negotiations, the general principles to be observed for the implementation of equal pay." As a result, definitions other than those set out in the Act and methods of comparison have never been specified (despite the case taken to the Court in 1975 by Woolworths NZ Ltd. and Wardell Brothers, where such guidance was sought). This means that equal pay for work of equal value has never been systematically applied; and in practice has been introduced partly through comparisons of the kind envisaged in the 1972 Australian decision and partly through job evaluation exercises which included the concept of the value of jobs to an employer.

Although the New Zealand male/female earnings gap narrowed in the private sector during the implementation period of the Equal Pay Act $(1973-77)$, it has remained approximately static since then. A series of adverse Arbitration Court decisions increased pressure for a review of the Act (12). 
The New Zealand Harbour Board Employee's Case, decided in 1979, concerned the question of whether certain clerical employees, predominantly if not exclusively women, could move on to steps 9 and 10 of the extended general Clerical Scale of the relevant award. Prior to the Equal Pay Act 1972 the Harbour Board Employee's award had contained separate tables for women and men, with a 9-step scale for women and a 14-step one for men. For instruments of this type the Act [Section 4(1)] required the relevant parties to carry out classifications of the work performed by female employees, and then set the rates which would represent equal pay for each classification. Then in December 1973 Clause la incorporating a series of work classifications was introduced into the award for the first time, and the extended 14-step scale was made available to both female and male clerical workers. Nevertheless, the Court determined that the workers specified in Clause 1a should not become automatically entitled to the extended 14-step clerical scale.

In three subsequent cases involving differential above award or non-award rates the Court held that no element of discrimination based on sex existed. These decisions were taken without calling on Section 2(2) of the Act, which permits differential rates of pay "by reason of special qualifications, experience, or other qualities possessed by that employee". whose probable effect would be to reduce even further the likelihood of a finding of discrimination.

In 1986, after the completion of the implementation period set by the New Zealand Equal Pay Act, the Clerical Workers Union took a case to the Arbitration Court seeking a ruling that employers should be directed to negotiate a claim for equal pay for work of equal value. The Court declined jurisdiction saying that the Act "contains no powers or other provisions by which the Court can address the issue raised by the Union and gives no powers to the Court to do what the union asks" (13). The ruling in practice meant that if awards had been registered during the 1973-77 implementation period the question of equal pay could not be raised. as their registration indicated their incorporation of equal pay principles. The Clerical Union case is likely to prove the last brought under existing legislation.

In 1986 an Equal Pay Study was commissioned in response to pressure for a review of the Act and its implementation by the Arbitration Court. The Phase One Report of the study indicated that the wording of the 1972 legislation, narrowly applied job classification exercises, inadequate policing of the Act, the possible use of discriminatory job titles and the narrow interpretation of Section $3(1)$ of the Act by the Arbitration Court meant, in effect, that the 1972 Act provided legislation to prevent discrimination based on sex in rates paid for equal work but was not successful in implementing equal pay for work of equal value (14). It was accordingly argued in the Report that new legislation was required in order to implement equal pay for work of equal value in New Zealand.

The Phase One Report also pointed to the need to develop adequate systems and procedures for use by employers and trade unions seeking to order jobs in a hierarchy reflecting their job value. 
In the beginning of March 1988, a Working group on Equal Opportunities, and Equal Pay was established to consider the reports of the Equal Pay Study and to make recommendations on further action. The Working Group's Report recommended new legislation involving a gender-neutral job evaluation scheme under which assessments would be undertaken by experts contracted by a Pay Equity Bureau which would also provide lay expertise to the Labour Court and the Arbitration Commission in matters relating to employment equity. It is also recommended that there be a facility for claims to be made by individual women, an individual woman or group of women who are part of a female occupational class, and unions claiming on behalf of members covered by the same award or agreement provided such unions can identify a female occupational class.

\section{Portugal}

Section 2(e) of Legislative Decree No. $392 / 79$ to guarantee equality of opportunity and treatment for women and men in matters of work and employment refers, without listing specific criteria, to duties which "although different in nature, are considered to be equivalent after the application of objective job assessment criteria". A formal system of classification covering all occupations according to skill levels was legally created in 1978 by the Law $121 / 78$ of 2 June, and established the following groups: experts; technicians; supervisors for men/women, team heads; highly skilled professionals; skilled professionals; semi-skilled professionals; unskilled professionals: and training and apprenticeship. The criteria associated with this system of classification apply to the stage of autonomy of each occupation and to the level of training required for its performance.

As far as wages or salaries are concerned, collective agreements adopt a simple hierarchical classification of jobs without any reference to the criteria used for establishing that classification. Work requiring physical effort, machine operation or any exercise of authority is given a higher value than manual work requiring accuracy, quickness or dexterity. Within this context each collective agreement defines, according to its own criteria, professional categories and hierarchies and their respective wages. Equal pay is evaluated in this context through the analysis of functions of different professional categories and of workers' insertion in different categories and associated hierarchies.

No cases have been brought to court under Legislative Decree No. 392/79. However, the legislation has been applied in relation to collective agreements. In Portugal as elsewhere, legislation exists which enables the effects of a collective agreement, which at first bound only the employers and workers represented by the bargaining parties, to be extended on the analogy of an award to all workers and employers in a particular branch of activity or geographical region. Such legislation provides a facility for the Government to require the observance of pay equity principles as a condition for granting such extensions. In 1980, the Portuguese Minister of Labour, on the advice of the Committee of Equality in Work and Employment, refused to extend discriminatory provisions contained in seven collective agreements which provided for discrimination in wages. 
In its 1982 report to the ILO, the Committee on Equality in Work and Employment noted that among the most common types of discrimination found in collective agreements in Portugal, the inclusion of occupations and occupational categories specifically meant for women was prominent:

In this type of agreement there are cases where different wages are attributed to identical occupations or occupational categories and others presenting discrimination with respect to occupations or professional categories that are nominally different, but where the content is exactly. the same. Explicit wage discrimination values are very significant in reported cases in 1981; the differences are in the order of 10 per cent, 23 per cent, 28 per cent and 50 per cent (15).

According to the 1985 comments of the General Union of Workers (UGT) concerning the application of the Recommendation 90 on Equal Remuneration, such collective agreements are to be found particularly in the agricultural sector; for example, the Beja collective labour agreement (BIE No. 40 of 29 October 1984) provides for two wage levels for agricultural workers, level A for men, and level $B$ which is applicable to women although the work done is in practice the same as that done be men.

The number of collective agreements in Portugal containing directly discriminatory provisions dropped from 8 ( 4.1 per cent) in 1979, 3 (1.8 per cent) in 1981, 2 ( 0.7 per cent) in 1982 to none to 1983 . The Commission for Equality in Work and Employment has received about 14 complaints of differential pay for equal work between 1981 and 1987, and provided information and advice on 7 of them (15).

\section{Japan}

The Labour Standards Act of 1947 does not incorporate a formal job evaluation scheme: neither does the 1986 Law concerning the Promotion of Equal Opportunity and Treatment between Men and Women in Employment and Other Measures for Women Workers.

A formal job evaluation scheme would not be pertinent to the Japanese wage-fixing system as it is presently constituted. This is because Japan has a traditional wage system in which wages are usually based on a worker's individual characteristics in conjunction with job categories. These individual characteristics include age, seniority, individual abilities and level of education. Wages are only rarely determined by occupational level: for example, keypunchers and other workers engaged in the operation of automated machines are ranked on the traditional wage scales as "general clerical workers" and rise on the seniority ladder in the same way as other clerical workers. Thus it is almost a rule that women in a firm who are hired in a specific year with the same educational background and status as "clerical workers" are paid the same basic rate even when they are engaged in different jobs. Similarly, wages in factories are not based on the individual worker but on a section or service in which that worker is employed. The traditional seniority system in which wage premiums are related to length of 
job tenure has had the effect of reducing women's overall earnings because Japanese women tend to leave the workforce for periods of child-rearing (though this tendency is decreasing) (16), and in addition enter the workforce with lower starting salaries.

A survey carried out by the Ministry of Labour in April 1981 revealed differences in the starting pay of men and women. These differences were attributed by the Government to differences associated with certain categories of work for which women might not be engaged, categories involving business travel, outdoor work, physical strength or special techniques or qualifications. The Japanese Confederation of Labour (DOMEI) in its comments to the ILO Committee of Experts on the Application of Conventions and Recommendations regarded the gaps in starting pay as discriminatory.

The Japanese Government has taken that view that the change from a seniority wage system to a wage system based on job content should theoretically promote the principle of equal remuneration for men and women by reducing the differences in earnings due to the shorter average length of women's service. However, it is also of the view that both employers and workers recognise the merits of the seniority-based wage system, and that it will have to be reformed gradually.

Because of the Japanese emphasis on seniority rather than work value, much Japanese legal action surrounding pay equity has been concerned with benefits supplementing the ordinary or basic wage. In the Akita Sogo Ginko case, which was judged at Akita District Court in 1975, it was argued that male workers had been paid living expenses in addition to their wages, while female workers had received no such expenses. As a result the 1970 wages of 35-year-old male workers were 1.4 times those of women workers of the same age. In its judgement the Court decided that the labour contract concerned was invalid under Article 4 of the Labour Standards Law, and that the women workers involved should receive the difference between their own and the men's wages.

In a second case the salaries of bank employees were supplemented by allowances accorded to heads of families. Whereas eligibility for this payment was in no way limited insofar as male employees were concerned, female employees only retained eligibility as long as their husbands' salaries remained below a specific level. The court interpreted the bank's salary regulations as reflecting a presumption by the bank that only males served as head of families (Judgement of the District Court of Morioka in the Iwate Bank case, 28 March 1985 cited in Legal Journal: Hanrejicho No. 1149). Accordingly, the court found that the criterion of sex was not justifiable and nullified the regulation in question. Since that time much attention has been given to rewording or clarifying the interpretation of terminology relating to recipients of non-wage benefits.

Similar concern has been generated by the terminology associated with or used to account for sex differentiating job classification systems. A decision handed, down on 4 December 1986, by the Toyko District Court nullified the collective agreement between the Japan Iron and Steel Federation and its secretariat's union providing for two different tables of wage increase rates, 
and bonus rates, one for men and the other for women. The Court rejected the Federation's argument that the category of 'men' was in fact that of 'nucleus employees' and that of 'women' was 'supplementary employees' and that the difference in remuneration was based on the different categories of jobs.

Since then, DOMEI has expressed concern to the ILO Committee of experts on the existence of a new classification which distinguishes between 'main or key work' and 'supplementary work', and in effect stipulates different career courses (or tracks) for managerial employees, on the one hand, and clerical (or operative) employees, on the other.

\section{Belgium}

In Belgium the questions of comparison of work value, nondiscriminatory skill scales and pay criteria have mainly been raised in connection with Collective Labour Agreement (C.C.T.) No. 25 rather than with legislation. In practice, the concept of work value has proved difficult to define. The best-known case was a dispute in which it was necessary to ascertain not only whether a salesgirl performed work of equal worth to that performed by her male colleagues (given that back pains prevented her from lifting heavy weights as those they lifted), but also whether the elements going to make up their respective wages were the same. In this case, the Antwerp Labour Tribunal, on. 21 December 1982, requested the opinion of the Specialised Commission set up within the "Conseil National du Travail" (National Labour Board) by C.C.T. No. 25, and the value of this mechanism was demonstrated. However, for procedural reasons, no definitive ruling was pronounced.

The devising of non-discriminatory skill scales has always been a highly contentious issue, but until 1986 did not give rise to any real disputes. In that year a group of female workers in a major electrical engineering plant complained that because of a partial revision of the scales applying in the firm, they had become less well paid than some of the less-skilled male workers. In its ruling of 22 September 1988, the Liege Labour Tribunal decided to place the issue before the Specialised Commission of the National Labour Council. Since the employer had appealed against the ruling, the Commission was unable to give an opinion and the Labour Tribunal's decision is still pending.

The question of so-called objective criteria justifying differences in pay has only come before the courts in connection with collective agreements negotiated in the industrial council for multiple stores. Under these agreements, different basic wages are paid depending whether or not the branch manager is deemed to be "fully employed", a notion depending on whether or not his/her spouse is gainfully employed. In a Judgement of 14 January 1983, the Brussels Appeals Court considered that these provisions were not discriminatory towards women for the purposes of Article 119 of the Treaty of Rome and Article 6 of the Belgian Constitution. More recently, the Liege Labour Tribunal, in a Judgement of 28 April 1986, decided that these agreements were not illegal in a dispute where a male worker complained that he was not receiving the guaranteed minimum industrial wage and where discrimination on grounds of sex was not alleged. 
While both public and private sector workers in Belgium are covered by Article 128 of the Act of 4 August 1978, private sector workers have generally had recourse to Collective Labour Agreement (C.C.T.) No. 25. Thus the effectiveness of the legislation has only been tested in the public sector. where implementation of the equal pay principle has raised few difficulties.

There was, however, discrimination at one time against female civil servants in the criteria for the award of a household or residence allowance, but equality was reinstated by a Royal Order of 10 September 1981, after the Commission of the European Communities took Belgium to the European Court of Justice. Since then, only one case of direct discrimination has been found: in the Ministry of Communications and the public bodies attached to it. dependants of male officials are granted free or cheap travel vouchers, but not dependants of female officials. The Ministry. has always cited lack of funds as the ground for not introducing equality. The issue is still pending.

\section{Denmark}

In Denmark the collective agreement is an important instrument of labour law. For this reason and because of the interaction of arbitration and judicial decision-making. Danish national case law reported here refers to both arbitration and settlements in court. Generally speaking there is a view that the purpose of including provisions concerning equal pay in a collective agreement is that disputes are in such cases settled by the procedures agreed upon for settlement of industrial disputes, and not by the ordinary courts of law.

Formal job evaluation schemes are not found in Denmark. Case law concerning equal pay comprises four awards given in connection with arbitration, one settlement in court, and a judgement delivered by the Maritime and Commercial Court of Copenhagen. An appeal against this judgement has been brought before the Danish Supreme Court.

The first case is an award from 1977 and concerns FDB (the Association of Danish Co-operative Stores). The case concerned the packing division of FDB where two groups of unskilled workers were employed at making goods ready for delivery to FDB's stores. In this case the umpire stated that an evaluation of equal pay should be made on the basis of "a direct evaluation. independent of the general wage formation - of the contribution of the groups of workers concerned to the stage in the production process to which the dispute was related". The emphasis was put on the actual work performed. The umpire held that the work performed by the two groups was to make goods ready for delivery and found that the work of the two groups was of the same value for and in the production at the workplace. Consequently it was found that the men and women should receive the same basic wage.

On 11 February 1985 an award was given in the case dealing with Vejle Amts Folkeblad (a newspaper). In this case female clerical workers were in part of their working time performing the same task - namely typing of advertisements on a visual display unit - as their male colleagues who were compositors. The groups were covered by two different minimum wage agreements. 
The umpire found that it was irrelevant for an evaluation of the equal pay question to compare the actual work functions performed by the two groups of skilled workers. Instead the question of equal pay should be decided for the fields covered by the collective agreements individually, in which case there were no problems concerning equal pay.

The 1977 decision cited above was followed by an award made on 29 April 1987 concerning KAD (the Union of Female Workers in Denmark) against the Employer Association of Wholesalers on Copenhagen on behalf of Premier IS A/S. KAD had - before the case: was referred to arbitration - asked the Danish Equality Council for its opinion. The Danish Equality Council found that the wage system was in conflict with the Equal Pay Act, but the employers' representative in the Council found that the question of whether it was work of the same value should be settled by arbitration.

In the event, the umpire found that male workers had for rather long periods of time been employed at work which corresponded to that performed by the female workers. As it was a question of the same work or at least work of the same value, the unequal wage was found to be in violation of the Equal Pay Act. The umpire reduced the claim for compensation for the differences in wages in respect of the preceding period to $2 / 3$ with reference to the fact that KAD had waited more than 1 year after the meeting between the organisations before it proceeded with the case by approaching the Equality Council.

Other cases reported concerned pensions for part-time workers and valuing changing work functions.

\section{Sweden}

No formal definition of equal pay is used in Sweden apart from that provided by the ILO convention on equal pay. The approach to pay equality adopted by the Swedish government has been to confine itself to a few basic principles and then leave it to the major parties to fashion whatever detailed rules may be required within those principles. The Swedish system of collective bargaining implies that labour market organisations are free to reach their own agreements on pay and working conditions. This means that they are free to decide upon definitions of equal pay taking into account what is regulated in the Act on Equality between Men and Women at Work. The Swedish Court has thus been obliged when addressing pay equity legislation to consider as a matter of priority the relation between the law and collective agreements. A collective agreement can however be nullified by the Labour Court if it is violating the Equal Opportunities Act.

Similarly, there is no formal job evaluation scheme for use in a a legislative context. While there are job evaluation systems for industrial workers, these systems are not aimed at reducing or eliminating sex-related wage differences. 
On 19 December 1984 the Labour Court returned its first sentence in a pay discrimination case under Section $4(1)$ of the Act Concerning Equality of Women and Men at Work. The plaintiff in the proceedings, which concerned the county council sector, was the Swedish National Union of Local Government officers (SKTF). Two women, both members of SKTE, were employed by the Stockholm County Council as form designers. They were both Senior clerical Officers in salary grade K 22. A man was employed on form design in another department of the same county council, as a Secretary in salary grade K 27. These salary gradings as Senior Clerical Officer and Secretary were governed by collective agreements between the county council and SKTF. The point at issue was whether the county council had been guilty of pay discrimination under Section 4 (1) of the Act Concerning Equality of Women and Men at work by paying the women a lower salary than the man.

The court began by examining a question of general applicability to the ban on pay discrimination, namely whether the employees to whom a comparison refers have their conditions of service defined by collective agreement. Referring to the travaux préparatoires of the Equal Opportunities Act. the court found that the existence of a collective agreement restricted the competence of common courts in that implementation of the ban on pay discrimination should not be allowed to interfere with the valuation of different jobs and the other wage-fixing principles applying in the labour market. On the other hand the court ruled that this was not to imply that Section 4(1) of the Act concerning Equality of Women and Men at Work was inapplicable to a case of the present kind.

Concerning the crucial relevance or otherwise of the collective agreement in deciding whether the duties involved could be considered equal. the court took the view that the agreement in question was too generalised to justify the inference that the women and the man, in the eyes of the contracting parties, were doing different jobs. The court thus disallowed the County Council's first argument.

In the matter of the method of testing to be applied to situations of this kind, the court ruled that a comparison of different jobs must focus on such outward indications as the nature and content of the duties and conditions in which they are performed; that any differences must be valued with reference to their nature and the frequency with which they occurred: and that the purpose of evaluation must be to decide whether the differences were of such a kind that one should expect them to be reflected by the conditions of service.

The case was dismissed, but the decision was not unanimous. It included a dissenting opinion which highlighed the difficulty of knowing how exactly one is to tell whether or not employees are engaged at equal work. The members of the court disagreed on this point. The minority, for example, drew attention to the fact that jobs can be described in various ways and can be given a higher or lower profile depending on who describes them, the implication being that women and men do not describe the same phenomena in the same language. 


\section{Finland}

In the preamble to the Einnish Equality Act it is stated that, in connection with job comparisons, attention should be paid to the type and content of the working conditions involved. Concerning those engaged in work of equal value, it is specifically stated that the comparison should be based on the practice or agreed norms that are observed in the various occupations. that is, in the classification of jobs.

Quite varying classifications of jobs are used in Einnish collective agreements. Within the metal industry, for example, negotiations have been going on for several years concerning the reform of the job classification system. There are no general guidelines concerning job classification: the matter is dealt with in instruction booklets on wages, etc. In common practice assessments are based, using varying expressions, on edication and training, experience, working conditions and responsibility.

The equality authorities have dealt with certain cases concerning equal pay. In some of them it has been recommended that the wages of a female employee should be raised with reference to the equal. value of the work concerned. The decision to implement the finding has been left to the employer, and in some cases the situation has been remedied.

\section{Turkey}

Pay equity in Turkey is determined by legislation in the public sector (Turkish Labour Acts No. 931 and 1475) and by collective agreements in the private sector. Formal job evaluation schemes are applied in both legislative and industrial contexts. There are a number of methods of job evaluation: ranking, classification and point factor comparison. Different sets of factors such as education, training, responsibility and working conditions are taken into consideration under each method.

Within the public sector centralised wage fixation applies to government employees while workers in State Economic Enterprises rely on workplace collective bargaining, as also do private sector establishments. Equal remuneration and comparable worth are formally defined in collective agreements, having been first introduced in Turkish industrial relations by the public sector in 1952 .

\section{Industrial Experience}

Industrial activity linked to pay equity tends to spring from either legislation or collective agreements depending on whether the national wage-fixing system is centralised or decentralised. In relatively decentralised systems unions are enabled by legislation to bring pay equity cases on behalf of their members. In addition, legislation may stimulate collective bargaining or create a context in which unions are expected by members to address equity issues. 
In Australia and the reporting Scandanavian countries, 'industrial action rather than legislation has been the main vehicle for raising pay equity issues. Collective agreements calling for equal pay for work of equal value mainly pre-date pay equity legislation in these countries and because of their coverage may be considerably more effective than legislation, particularly legislation which does not permit class actions. In highly centralised systems industrial action may also be more effective in reducing pay differentials because the relatively weaker bargaining position of unions covering female-dominated areas is strengthened through collective action and collective policies for assisting the low paid.

\section{Great Britain}

Trade union membership in Great Britain is comparatively large and national agreements set minimum rates of pay in a wide range of industries. The fifteen largest national wage agreements cover around one fourth of the workforce. The four largest agreements cover almost one-fifth of the workforce. There is, however, no overall centralised wage-fixing system in Great Britain. Voluntary collective bargaining is conducted at national level in some industries and services and at company or plant level in others; in some cases, wages and conditions of employment are determined by a combination of national and local bargaining.

There is no standard definition of equal pay for industrial relations purposes. It is a matter for employers, or for the parties engaged in collective bargaining, to ensure that their payment systems and pay agreements conform with the relevant equal pay legislation. Whether or not to introduce formal job evaluation schemes is also a matter for employers or for the parties engaged in collective bargaining. The criteria and other details of such schemes are a matter for negotiation in that context. There is no standard practice amongst British employers, although the Advisory Conciliacion and Arbitration Service and the Equal Opportunities Commission do provide guidance on implementing job evaluation schemes:

Unions have characteristically preferred to use traditional collective bargaining arrangements rather then claims under the Equal Pay Act to negotiate better pay for all low paid members. Use of the law as a bargaining lever to negotiate increases in the wages of their female members is seen as preferable to pursuing often lengthy and uncertain cases through the tribunals.

- Baking industry workers. The industry reached a pay settlement in 1986 which abolished the lowest grade (mainly women) and had the effect of relatively improving the pay of those concerned. This was negotiated in response to union arguments specifically based on equal pay principles.

- Local authority manual workers. The findings of a comprehensive job evaluation exercise in 1986, based on equal value principles, formed the basis of a major restructuring of grades negotiated and agreed in 1987. Many jobs were revalued. For example, home helps, who are mainly female, were promoted up the structure and received relative improvements in pay. 
- National Health Service workers. Some regrading on equal value principles has been agreed for NHS ancillary staff following the unions claim in 1986. However, the unions believe that the revised structure still fails fully to reflect the principles of equal pay for work of equal value and both sides are continuing to discuss this issue. Staff evidence to the Pay Review Body for nurses and midwives has cited the equal pay legislation in support of pay claims but no restructuring has resulted so far. Three test claims under the equal pay legislation by NHS speech therapists are to be heard by an industrial tribunal as a result of an appeal to the High Court. The claims are for parity with pharmacists and clinical psychologists and the outcome could be influential elsewhere in the Health Service.

\section{Canada}

Canada does not have a centralised wage-fixing system; rather, earnings
levels are established through workplace collective bargaining on an occupational basis. A number of employee associations have taken up equal pay as an issue. This is particularly true in public sector unions, where women form a significant percentage of the membership. Examples include the umbrella Canada Labour Congress and its affiliates such as the Public Service Alliance, the Canadian Union of Public Employees, and the National Union of Provincial Government Employees, which is also an umbrella union for each of the provincial public service employee unions. In addition, a number of labour federations such as the Ontario Federation of Labour have taken up the issue.

Activities undertaken by unions include: collective bargaining; participation on joint job evaluation committees comprised of union members and employers: submission of complaints to human rights commissions: the establishment of women's branches, specialised staff and committees within the union; and the development of courses, conferences and publications to increase the awareness and understanding of the issue among members.

One of the first attempts to bargain for equal pay for work of equal value was made by the Canadian Union of Public Employees (CUPE) on behalf of the 72 per cent female support staff at the Winnipeg Health Sciences Centre. The parties ultimately agreed in negotiation to new wage rates based on the results of the job evaluation plan, which narrowed the average monthly salary differences between males and females from $\$ 109$ to $\$ 29$. Ninety-three per cent of the pay increases required by the program went to female employees.

In 1981, in a campaign entitled "Equal Pay is Fair Pay". CUPE took more than 11000 British Columbia Lower Mainland Civic Library and school board workers out on strike for up to 15 weeks to back their demands for equal pay for work of equal value. While refusing to acknowledge the equal value principle. negotiators were able to distribute the fairly generous wage increase as they saw fit. provided only that the inside clerical workers received percentage and not across the board rises. The parties finally approved a one-time lump sum bonus payment for the inside clerical workers as a way to address the problem. In addition, the negotiating committee used some 
of the money to restructure the pay plan. Increases of 6.8 per cent were given to the lowest pay grades while the highest ones received only 0.2 per cent. The original 33 pay grades were significantly reduced in number. All grades below 9 were abolished while many grades were collapsed into one, which had the effect of further reducing the wage gaps.

The Ontario Public Service Employees Union (OPSEU) recently signed a collective agreement with the province's 22 community colleges, which covers 4700 support workers. The union was able to negotiate participation in a province-wide point classification system which it hopes will pave the way for identifying pay disparities (17).

\section{United States}

The United States has neither a centralised wage-fixing system nor centralised collective bargaining. In addition, only 18 per cent of the US workforce are union members. In practice the federal minimum wage sets a widely-applicable base above which employers and employees may negotiate wages. Where the company has a collective bargaining agreement, pay scales are subject to collective bargaining.

A number of unions have taken leadership roles on pay equity matters. although unions differ on the emphasis that should be placed on the issue. Some see it as a basis for expanding membership. particularly in occupations dominated by women. Among the strategies used by unions are litigation, support for state legislation directed at the salaries of public employees. and education of members through publications and meetings. Model contract language has been developed by some unions. Through collective bargaining unions have pressed for a commitment to equal pay for work of comparable value, and more specifically for employer/union studies of job classifications and wage rates for use in detecting discrimination, "upgrading 'women's jobs'" and negotiating "equity increases". Grievance and arbitration procedures also have been used to correct wage inequities.

A landmark industrial dispute occurred in San Jose in 1981 when a comparison of the pay of men and women working at jobs which were different but which were claimed to be equal in value, was negotiated through a formal collective bargaining process. When negotiations reached an impasse, the matter became the cause of a strike by municipal employees in the first direct industrial action over the issue. In their negotiations the state authorities and the union, the American Federation of State, County and Municipal Employees (AFSCME) sought the use of the Hay Guide Chart-Profile Method of Job Evaluation and the city council authorised the study with the stipulation that there was no commitment to do anything other than review the results.

The settlement, reached after nine days of striking, allocated $\$ 1.4$ million over two years for extra "internal equity adjustments" to "predominantly female-dominated positions" over and above general pay increases. Under the settlement, the city acknowledged equal pay for work of equal value as a legitimate issue, but stopped short of adopting it as a salary policy. 
Employers in the United States generally support the concept of equal pay for equal work (as defined in the Equal Pay Act) and few would quarrel with the premise that wages should be based on work performed, not on the sex of the worker. Nevertheless, employers express serious concerns about proposals for equal pay for jobs of "comparable worth". Among other things, they take the view that judges and courts do not have sufficient technical expertise to determine the worth of $a$ job and that government intervention in salary determination would prove disruptive and unworkable, and would lead to rising business costs and inflation. They also fear that this rise in costs would affect competitiveness in world markets.

Public employers and large companies have used job evaluation plans and job classification systems for decades to bring some kind of order and rationale into the wage-setting process. However, employers stress the need to take supply and demand into account in any wage-setting system. Several employers nevertheless have taken steps to examine their own job evaluation and classification systems as a part of assessing the fairness of their own employment practices. For example, as new technology rapidly changed the content of jobs and the qualifications needed to fill them, one major company invited unions to take part in the committees that identified job factors and estimated the importance of those factors, laying the groundwork for wage determinations. A number of management consulting firms have specialised in providing legal and technical advice to companies facing the complexities of reassessing their systems of wage determination.

\section{Australia}

Formal wage determination in Australia is regulated and centralised. About 85 per cent of employees have their wage rates determined either wholly or in part by awards of industrial tribunals established by either federal or state legislation.

While more employees are covered by state than by federal awards, the federal industrial tribunal - the Conciliation and Arbitration Commission (now the Industrial Relations Commission) - is the most important wage-fixing body, as State tribunals tend to follow its lead in wage matters. In particular, national wage increases granted by the federal tribunal usually flow, via the state tribunals, to workers employed under state awards. In some industries over-award payments are widespread and constitute an important component of overall remuneration. Such pay is usually fixed by direct negotiation between employers and unions. Parties to wage disputes are employers, whose peak national body for the wage case is the Confederation of Australian Industry (the CAI) and trade unions, whose peak body is the Australian Council of Trade Unions (the ACTU).

On 7 May 1987, in response to a claim brought by the ACTU, a Full Bench of the Australian Conciliation and Arbitration Commission decided that there should be increased rates of pay for all nurses under the 1985 "comparable worth" claim. However, there was in the decision no attempt to specify which components of the increased rates of pay represented a response to equal pay anomaly claims, and which applied to work value changes and inequities between nurses in public hospitals and nurses in Department of Veterans' Affairs Hospitals. 
In a separate State claim, the Victorian Registered Nurses' Pay Case of early 1986, a pay history of State nurses presented to the Victorian Industrial Relations Commission showed sex bias in the nurses' pay. Female nurses had been paid not only a lower basic wage but also a lower margin for skill than their male counterparts. When the difference in rates was deleted the rate of male and female nurses was based on the lower female margin for skill. Moreover, comparisons showed that nurses were paid low wages relative to other occupations in the health industry.

In its decision of 20 June 1986, the Victorian Industrial Relations Commission found the existence of an anomaly regarding, inter alia, the non-application of the 1972 Equal Pay Principle, and granted pay increases accordingly.

Similarly, increases received on a State claim by South Australian registered nurses in 1986 were solely attributable to the implementation of previously unapplied equal pay for work of equal value principles. This factor also contributed, together with work value, to increases received by higher classifications. Subsequent applications for pay increases for nurses in all jurisdictions have been based on work value grounds and on the introduction of career structures.

In relation to pay differentials associated with over-award payments. the ACTU is of the view that the matter is being addressed through the Supplementary Payment Principle, re-introduced as one ground for pay claims in the 1987 wage fixing system after having affected a small number of federal awards in a previous system. Approved by the Conciliation and Arbitration Commission as part of the 1988 National Wage Case, the Supplementary Payment Principle was designed to reduce wage inequalities by reducing differentials between the highest and lowest paid workers in an award . through a "floor-raising" exercise: As a result of this strategy, some groups of women workers, notably those in the textile. clothing and commercial clerical sectors, have made some gains.

The current restructuring of awards to broaden the skill levels and flexibility of Australian workers is likely to involve skill audits and job reclassification exercises which are in turn likely to affect the current valuing of work which is predominantly done by women. In its May 1989 decision following a Review of the Structural Efficiency Principle, the Industrial Relations Commission found that there existed in federal awards widespread examples of the prescription of different rates of pay for employees performing the same work, as well as inequitable relationships among various classifications of employees.

In its decision in the August 1989 National Wage Case the Commission considered that without firm guidance on appropriate relativities, individual structural efficiency exercises could create situations which exacerbated such inequitable relationships. Accordingly it specified ranges of the percentages of the tradesperson rate for key classifications in metals, stores and transport within which relativities should be established. It decided that minimum rates of pay for classifications and supplementary payments for other 
classifications throughout industrial awards should be set in individual cases in relation to the metal and building tradesperson rate on the basis of relative skill, responsibility and the conditions under which the work is normally performed. The impact of this decision on gender wage differentials will not be able to be evaluated until all new relativities are established.

\section{New Zealand}

Until fairly recently. New Zealand has had a 'combination' wage fixing system whereby wages have been determined by centralised wage-fixing and workplace collective bargaining. Earnings levels have been largely set on an occupational basis, through negotiations and arbitration. Recently new legislation to encourage bargaining on an enterprise or industry basis has been introduced. However, it would appear that so far in the private sector national awards continue to exist and that it is likely they will remain in the areas that are most affected by a pay equity claim, namely, low paid female-dominated occupations. Many agreements are already determined on an enterprise or industry basis and it is likely that many more settlements will be made on this basis rather than on an occupational basis.

Since the ruling in the Clerical Workers case of 1986, all formal instruments specifying rates of remuneration in both the Government and private sectors by definition contain rates designed to reward skill. responsibility and service, without discrimination on the basis of sex. It is still the case that unions and employers can collectively negotiate wage claims on the basis of equal pay for work of equal value through the award system (that is, through conciliation and voluntary arbitration) of through an agreement. However, since the 1986 Clerical Workers decision, there must be agreement between unions and employers. In general there are no legislative means by which employers can be obliged to pay on the basis of equal pay for work of equal value. If employers were to agree to equal value claims, agreements would apply to a single employer, enterprise or industry while awards would apply to an occupational group across employers.

In 1987, 263622 New Zealand women were members of unions affiliated to the Federation of Labour. giving it a 34.1 per cent female membership. Both the "Clerical Workers Union and the Nurses Association, which have predominantly female membership, have taken up equal pay as an issue and remained vocal in this area since the 1986 decision in the Clerical Workers Case. The Clerical Workers Union has presented a petition to Parliament to have legislation on equal pay for work of equal value introduced.

\section{Portugal}

Wages in Portugal are set in collective agreements negotiated on an industry basis or at enterprise and occupation level. Each agreement defines hierarchies and professional categories and related remuneration according to its own criteria. Collective agreements do not generally clearly enshrine the principle of equal pay, and when they do so simply reproduce the terms of the law. 
Some workers' organisations have undertaken industrial activity in support of pay equity. Their main activity consists in putting forward proposals for collective bargaining aimed at correcting wage discrimination, putting forward complaints to the Committee for. Equality in Work and Employment, and providing workers with the information on wage discrimination.

\section{Japan}

In Japan the wage fixation is mainly done in the "Shunto" (Spring Wage Offensive). Shunto is a process in which individual enterprise unions - most of the unions are based on the enterprise in Japan -- simultaneously submit their demands for wage increases and negotiate with their respective employers under the direction and co-ordination of national centres and industrial organisations. The average increase of wages in Shunto is reflected in the wage increase for workers in small and medium enterprises and for national public servants. The Shunto system has been fully operative since 1956, and like the seniority system has taken its place as a wage determination process peculiar to Japan. Intractable industrial disputes concerning wages are referred for conciliation, mediation or arbitration to the Labour Relations Commission established under the Labour Relations Adjustment Law.

Trade unions in Japan have adopted policies including equal employment opportunity and treatment between men and women, and positive application of the 1986 Equal Opportunity Law. The trade unions having such policies include the General Council of Trade Unions (Sohyo), the Japanese Federation of Textile Garments, the Chemical, Distributive, and Allied Industry Workers' Unions and the Japanese Federation of Rubber Workers' Unions. The kind of activity undertaken by unions includes monitoring and reporting on practices which, given the present seniority system, are likely to have the effect of maintaining differential rates of pay. These include sex-differentiated recruitment practices and the failure to implement child care (maternity) leave.

\section{Greece}

In Greece the determination of salaries and conditions of employment is managed through collective agreements between the social partners, who have recourse to arbitration in the case of disagreement. There is no formal system for evaluation of distinct employment classifications. Greece reports that in line with Constitutional requirements, agreements currently being reached do not incorporate discriminatory provisions.

The Greek National Collective Agreement of 1975 sanctioned the principle of equal remuneration for work of equal value and was further extended in 1978 . Workers' organisations continue to address the matter of equal remuneration. In the last resort they may have recourse to the provisions of Law 1414/84 on the Application of the principle of equality of the sexes in working relations. 


\section{Belgium}

With two out of every three employees organised. Belgium has in fact one of the highest levels of unionisation of any market economy. Since 1960 . collective bargaining in Belgium has been carried on in accordance with the principle known as social programming. Social programming reflects the idea that by working in concert and taking account of objective criteria, the workers' share in the growth of the national wealth will be programmed over a certain fixed period. Collective agreements which result from this social understanding are called social programming agreements. There is no doubt that social programming has favoured the centralisation of collective bargaining; nationwide industry agreements have had an important effect on the overall climate of labour relations, while most industrial sectors are covered by national agreements.

Collective Labour Agreement (C.C.T.) No. 25 of 1975 proscribes wage discrimination in the private sector, whether direct or indirect; it covers both "equal work" and "work of equal worth"; it requires full equality to be achieved not only in the wage structure but also in job rating systems. C.C.T. No. 25 has achieved its object (which was in any case rendered mandatory in Belgium by EEC Directive 75/117), by forcing the revision of sectoral collective bargaining agreements that were directly discriminatory (providing differing wages for equal work). By now all sectoral collective agreements have been brought into line and, it is believed, most company agreements. Some direct discrimination may still exist in corporate practice, but the Inspectorat des lois sociales (social legislation inspectorate) has found very few cases (less than ten a year).

C.C.T. No. 25 of the Conseil National du Travail ensures that part-time workers are paid pro rata at the same rate as full-time workers. This system does not hence give rise to any direct wage discrimination. However, it has come under attack for its indirect discriminatory impact since some employers systematically reserve part-time work for female workers. However, the problem has come before the courts only in connection with equal treatment in a firm where, on economic grounds, the management decided to introduce part-time working for all employees who were not heads of household, i.e. primarily women. The judgement in this case by the Charleroi industrial court on 12 November 1984 only found against the employer for illegally laying off female workers who had taken strike action in protest against the reduction in their pay.

\section{Denmark}

In Denmark the collective agreement has a binding effect, and so is enforceable by the Labour Court. Furthermore it gains importance, because it is a basic legal principle in Danish labour law that the organisations of employers and wage earners in a very wide sense have the right to make agreements binding the members to rules laid down in the items of the agreement. The Danish system of labour law is founded upon theories of combination, and the collective agreement is considered to bind the organisation as well as the members. 
Danish collective agreements first addressed the matter of pay equity in a settlement proposed by the Public Conciliator on 27 February 1971 which led directly to a narrowing down of the gap between the basic wages of men and women. By the adoption of the settlement of 27 March 1973 equal pay was introduced in those occupational fields which are covered by agreements between the Federation of Danish Trade Unions and the Danish Employers' Confederation. The settlement also had an impact on those parts of the labour market which were directly covered by the settlement, and especially on the private labour market.

Since that time equal pay matters have been supervised by among others, the KAD (the Union of Women Workers) the HK (the Clerical Workers Union) and the Union of Domestic workers (see previous section).

\section{Sweden}

The principle of equal pay has been laid down in collective agreements on equal opportunities which have been concluded in both the private and the public sector. However, employees associations in Sweden have primarily taken up the equalisation of wage-levels as a question concerning the distribution of incomes and wealth between social classes and between different groups of wage-earners.

The Wage Solidarity policy, which the trade unions in Sweden have implemented since the late 1950s, relies on a co-ordinated effort on the part of the unions to protect low-paid groups which have traditionally lagged behind in wage offensives. Under the policy, all wage groups pursue a centrally-agreed set of increases which are sufficient to maintain and improve the lot of the low-paid, while at the same time taking current economic circumstances into account. The principle that workers should receive equal pay for work of equal value irrespective of the profitability or capacity to pay of the particular firm is also central to this approach. 'In central negotiations, therefore, the principle of higher wage demands per se has to a certain extent been replaced by a co-ordinated and co-operative offensive on low wages tied to the pursuit of greater equality in the wage structure.

As a result of the Swedish Wage Solidarity policy pay differentials between women and men in Sweden are comparatively small; in 1975 women in full-time employment earned 74 per cent of men's earnings, but by 1981 this figure had risen to 80 per cent. The differentials in industry are even smaller with women adult full-time ordinary industrial workers earning 90.2 per cent of the adult male hourly rate in 1986.

Very few special initiatives have been taken towards achieving equal pay. However, the Section for State Employees within the central Organization of Salaried Employees has requested increases in women's wages on the basis of equal pay. In 19880.1 per cent of the wage-sum awarded was allotted specifically to occupations dominated by women. 


\section{Finland}

Finnish collective agreements are nation-wide and relate to each particular trade (trade union). The most important collective agreements for the public sector apply separately for central and local government. In addition, nation-wide centralised labour market agreements address, for example, reforms of social welfare and labour legislation. In the private sector it is possible to a certain - though limited - extent to negotiate on wages relating to a particular enterprise.

Issues concerning equal pay have not as yet been dealt with in the labour market agreements to any considerable extent, but the aim has been to attend to them in connection with negotiations on other wage issues. In the autumn of 1988 the central labour market parties accepted an equality item, the use of which is negotiated by each trade. The amount of the equality item is specified so that hourly wages of 10 Finnish pennis (about US\$ 0.025) are multiplied by the number of women working in the trade covered by the agreement.

In particular, all the central labour market organisations take a favourable view of equal pay issues. Perhaps the Central Organisation of Finnish Trade Unions (SAK) and the Confederation of Salaried Employees (TVK) have tackled the issue most vigorously. Measures have mainly focused on the problems of the definition of work of equal value.

\section{Turkex}

In Turkey earnings levels are set primarily on an industry basis. While this may be done through national negotiations, settlement may be sought by arbitration if national negotiations do not result in agreement.

Turkish employees'. associations have not taken up equal pay as an issue.

\section{IDENTIFYING DEMANDS ON EMPLOYEES}

In a number of countries both legislation and collective agreements leave open the method of job evaluation to be applied, specifying only that it address effort, responsibility, skill and working conditions, and be free from gender bias. Research into job evaluation practices has pointed to specific grounds on which women's work has often been undervalued or even discounted in the analytic phase of establishing work value.

\section{Skills}

Because male-dominated fields are used as the norm, skills that are frequently ignored include the following (which is illustrative rather than comprehensive): 
- Manual Dexterity: Jobs conventionally occupied by women such as process work and keyboard work frequently involve significant levels of manual dexterity, whereas jobs conventionally occupied by men do not. Evaluation techniques sometimes do not take account of this skill while men's 'natural' facility for handling weights is rewarded.

- Interruptions and Simultaneous Tasks: Women's jobs such as secretarial and reception work, nursing and teaching tend to involve the capacity to sustain more frequent interruptions and to manage simultaneous tasks - skills which receive little or no attention in job rating system.

- Socially v. Mechanically Oriented Tasks: It has been noted with increasing frequency that many characteristically male occupations entail compensation for the handling of machinery, while women who characteristically occupy jobs oriented towards human care and social service are not regarded as exhibiting the same levels of skill and responsibility. Similarly, management of people is regarded as a more demanding social skill than motivating and educating them.

- Training and Certification: One of the major issues associated with the determination of work value is the interpretation of training and certification. Traditionally male occupations are more likely to be associated with formal preliminary training programs such as apprenticeships, while the equivalent women's skills (such as sewing) are taught in the home or informally on the job.

In addition, many jobs occupied by men are associated with on-the-job training while those occupied by women require skills which have been taught in advance (such as the language skills of secretaries) but are not taken into account.

These observations are supported by the data provided by the countries taking part in this study, who reported that occupations in which women dominate, that is, clerical, sales and service occupations, tended not to require formal certification. A 1983 survey of occupational training in the United States showed for example that the leading occupations for males and females differed quite markedly in the type and incidence of qualifying training. Workers in female occupations also reported a lower incidence of formal company training.

Finally, women's professional skills are likely to be assigned lower level institutional accreditation than traditionally male skills.

- Responsibility: Accountability is more readily measured in fiscal terms in organisations or sections of organisations in which profit margins are regarded as a significant determinant of success. These outcomes are less relevant to educational and other public sector occupations where women tend to be employed. 
- Working Conditions: There has been a tendency in the development and application of job evaluation schemes to identify negative aspects of working conditions with stereotypes provided by conventionally male jobs. Thus regard is had to dirt, noise, extremes of temperature and vibration; while attention is not directed to the working conditions faced by women such as cleaning toilets and laundering soiled clothing and bedding, and the faeces, blood and vomit to which nurses and nurse's aides are subjected.

While there is a number of features of analytical evaluation systems which in themselves exhibit a tendency to reproduce sex bias, there is in addition the factor of subjective bias on the part of those taking part in the analysis. Men are likely to overdescribe and women to underdescribe the same job, a tendency which could be exaggerated when sex-segregated occupations are under consideration. (18).

\section{IMPACT OF LEGISLATIVE AND INDUSTRIAL RESPONSES TO PAY EQUITY}

It is difficult to establish with any clarity the populations affected by the coverage of legislation and industrial agreements across the responding countries. Accordingly the impact of legislative and industrial action to achieve pay equity cannot be directly measured at this stage either in terms of the number of persons affected or in financial terms. Differences in the structure of the labour force across countries, differing definitions of employed and unemployed persons, and of full-time and part-time work, make comparisons difficult. It is, however, possible to look broadly at the limitations of legislation in terms of the number of persons to whom it applies and the impact it has had on earnings differentials.

\section{Population Affected by Legislation and Industrial Agreements}

In each case of legislation there are differences between public and private sector provision, or between levels of federal and state coverage. It is at least possible to specify briefly that, in terms of legislation:

- In Canada federal and provincial legislation cover between them about one-third of the population.

- In the United States federal. legislation covers most federal, State and local government workers and private employees covered by the Fair Labour Standards Act. Most States have legislation which is at least comparable to the provision at a federal level.

- In Great Britain legislation applies to all employees so long as a women's employer also employs men in the establishment where she works. Provided that certiain criteria are met, a woman can also claim equal pay with a man working at another establishment of the 
same employer or of an associated employer, even if there are no men working. at the same establishment. (Two employers are regarded as 'associated' if one is a company of which the other has control or if both are companies controlled by a third party.)

- In Australia all federal public sector and one State's awards are covered by anti-discrimination legislation. At. May 198383.6 per cent of male and 89.7 per cent of female employees were covered by award rates of pay. Industrial decisions or agreements affecting award rates of pay apply to all the workers covered by such awards.

- In New Zealand separate legislation applies to the private and public sector. However, since 1986 private sector application has been treated as having lapsed. The New Zealand Human Rights Commission Act empowers the Commission to bring proceedings on behalf of a class of persons. However, complaints relating solely to equal pay must be referred to the Secretary of Labour unless the complaint is made against the Crown.

- In Portugal legislation does not cover work at home and domestic service.

- Japanese legislation does not apply to businesses which employ only relatives living together, or to house helpers.

- In Belgium private sector workers are covered by legislation and Collective Labour Agreement (C.C.T.) No. 25; public sector workers are covered by legislation as well as having Constitutional rights.

- Danish legislation applies to all employers who employ both men and women. Legislation does not apply in cases in which a similar duty follows from a collective agreement.

- Swedish legislation applies to both the public and the private sector. A collective agreement can be nullified if it violates the legislation.

- Legislation in Finland applies to both the public and private sector excluding activities connected with religious communities and private or family relationships. Legislative provisions do not apply if they are inconsistent with a pre-existent collective bargaining agreement.

- Countries with legislation conforming to the requirements of the EEC 1975 Equal Pay Directive include Germany, Denmark, Belgium, Greece, Portugal, and Great Britain.

Regardless of the number of women who have theoretical access to pay equity legislation, its practical coverage is affected by its capacity to sustain class rather than individual actions. In countries such as Canada, Denmark and Finland class actions can be brought, while in Great Britain any action under the law must be taken individually. 
No data have been reported concerning the annual value of industrial agreements based on pay equity. In addition, research indicates that there has been a flow-on from covered to uncovered workers in Great Britain and Australia (19). For both reasons specification of the population affected in this category is not possible and broad trends only can be indicated.

\section{Implementation Issues}

The review of legislative and industrial mechanisms associated with equal pay has raised a number of issues with respect to its practical implementation in addition to some of the "technical" issues outlined in relation to the definition and accreditation of skills. While these vary from country to country, there appear to be some common issues, associated, for example, with the interpretation of some legislation and the arguments and definitions used. Some legislation may actually deter potential claimants, as its obscurity has lead to costly and time-consuming litigation. Should efforts be made to re-draft such legislation in the light of more efficient existing models?

In addition, the use of defences such as the "market factors" or material factors defence can also undercut the intention of legislation. Of the significant employer defences used at present primarily in the United States in relation to work that is not "substantially equal", the market factors and discriminatory intent arguments pose special difficulties because of problems associated with their definition and use.

The general methods of comparison used also present a major issue of implementation. Some argue that a comprehensive evaluation of all the jobs in a workplace is unnecessary to implement equal pay for work of equal value as it is time-consuming and costly. Are there simpler methods that avoid the expense and delay of job evaluation studies and comparative studies of historical relativities?

Other issues concerned with proper comparisons include the lack of a male comparator, the amount of pay adjustments, and the proportionate evaluation of work. Traditional equal value principles have not addressed the problem of women who like daycare workers may have no male comparator in their establishment or in establishments of the same or an associated employer.

There remains the question of how to adjust women's positions if there is more than one comparable male pay rate. Should the pay be raised to the highest, lowest or average of the comparison groups?. If the wages are moved up to the highest available work rate, will this generate further complaints of discrimination from employees in male job categories in the lower pay ranges? In addition, present laws are directed to equal rather than proportional evaluation and do not address the problems of a female worker who scores 75 per cent of the points accorded to a male worker yet is paid 50 per cent of his salary. Can collective bargaining proposals address this issue effectively? 
A problem which should be noted in relation to collective bargaining for equal pay for work of equal value is that there is by no means a necessary correspondence between equal pay for work of equal value and pay rates agreed through wage negotiation processes. Indeed, collective bargaining which issues in compromised rates of pay may contribute to fixing women's rates of pay below those established through work value assessments.

In relation to practical problems encountered on a workplace level. there is concern that employers will contract out work in order to avoid giving pay equity. In addition, unions have had difficulty in obtaining access to complete and accurate knowledge of job information and wage-setting practices. information which is crucial to the identification of pay inequities. This has been particularly difficult where the male comparison group is in another bargaining unit or in an unorganised unit. Should disclosure clauses be negotiated into collective agreements?. What role can other unions in an establishment play in sharing access to information?

Finally, and most generally, implementation of pay equity appears to be becoming increasingly dependent on union as well as government action. Such action is in turn directly related to women's union participation. While in the United Kingdom data on women's union participation is just beginning to become available, reports from the United States, Canada and Australia indicated that in those countries a smaller proportion of women than of men are unionised, but that in the two latter countries the rate of growth in unions is faster among women, while in the United States union membership as a percentage of employed persons is decreasing for both male and female workers. The proportion of women in Swedish Trade Unions has grown from 66.9 per cent in 1973 to 69.6 per cent in 1987, while in Finland in 1984 women slightly outnumbered men as a percentage of organised labour. In Japan the percentage of women trade unionists has remained stable at 27.6 per cent since 1965.

The reasons for women's generally lower proportion of unionisation are structural and historical. Many women work at home or in small enterprises, which are difficult for unions to contact easily. Another reason for women's proportionately lower unionisation may be their greater presence in part-time and casual employment which traditionally have had very low union representation. Women also tend to work in areas such as community services which are often not covered by industrial agreements. Nevertheless, as a number of reports indicate, unions are making efforts to attract women and to address their interests, partly in recognition of the shift of employment patterns toward traditionally female industries to which the American report points. As the preceding section on industrial activities for equal pay also makes clear, a number of unions in each of the participating countries. particularly in the public sector, have sought to improve the earnings position of their women members while preserving terms and conditions already extant for men. In addition, unions are seeking to raise their credibility with women by increasing women's representation at senior levels where they have thus far been notably under-represented.

Despite all these developments, it should be noted that union response to the increasing participation of women in the workforce has been uneven, due largely to industrial and occupational segregation, and to the relatively 
non-strategic position of women's conventional occupations in developed countries. These factors have contributed to differential wage-setting and to the low value placed on women's work hitherto.

\section{Impact Evaluations}

Figures 1 to 12 and the associated Tables 3 and 4 are based on earnings data supplied by some of the reporting countries. Great Britain, the United States and New Zealand have supplied hourly data; Australia has supplied weekly data in order to provide a series antedating the 1969 equal pay decision; and Canada has supplied annual data. Portuguese and Japanese data are based on monthly average earnings. which in the case of Portugal include overtime. Danish data is based on average hourly earnings for unskilled workers; Swedish data represents hourly earnings for adult full-time ordinary industrial workers; and Finnish data on hourly earnings applies only to workers in the manufacturing sector.

Given these variations no direct comparisons can be made, though the trends exhibited by the female/male earnings ratios over time for each country can be analysed and broad general observations suggested. It should also be noted that full-time data were requested and full time or average hourly data were received as the basis for establishing pay ratios. This means that the: very significant effect of part-time figures will not appear in the ratios provided, which will therefore exhibit lower differentials than is the case when all earnings are included. The earnings of outworkers and non-wage remuneration have also been excluded.

There are additional limitations on the conclusions which can be drawn from these data. The aggregate data cover changes in the composition of the labour force, and specifically the change in the proportion of female to male workers. It must also be remembered that observed wages may constitute only an upper portion of the distribution of wage offers, and that given the relatively lower labour force participation rates of women it may be necessary for any study of wage differentials to take into account the possibility of a selectivity bias.

\section{Impact of Lepislation and Collective Bargaining}

Between the years 1970 and 1986 the female/male pay ratio in Great Britain rose from 0.64 to 0.74 . Half of that rise occurred between 1974 and 1975. This significant change in pay ratios corresponds with the coming into force of the Equal Pay Act 1970 on 29 December 1975. When the Act was passed in 1970 employers were given a 5 year implementation period during which to bring their wages systems into compliance with the Act. Subsequent study has indicated that most organisations made very little use of the 5-year period for implementation (20) and it appears from the material submitted that most of the effective changes which were made took place in the final 1974-75 period. 
The most immediately effective provisions of the were those set out in Section 3, which applied to collective agreements whether or not they were employed British Equal Pay Act all women covered by same as or substantially similar to that of male employees. Section 3 was thus meant to ensure that all those women in sex-segregated occupations received some increase under the Act. What Section 3 provided was that in workplaces covered by collective agreements women could not be paid at less than the lowest male rate. It thus operated across the board at a time when collective agreements could be referred to the Central Arbitration Committee under the Act.

The 1984 amendment to the British Act to extend equal pay to occupationally segregated women does not appear to have significantly affected the female/male pay ratio, which has fluctuated between 0.71 and 0.74 since 1975. It has been argued that a case by case legislative format with an uncertain interpretation and no facility for class actions is unlikely to result in such statistically significant results as an across the board action such as the Section 3 provision (21).

While the data supplied for this study from the United States only cover the period 1979-86. other research indicates that the federal legislation in that country has had a minimal direct impact on relative earnings (22). In addition, data reported to the OECD (based on Current Population Reports for the period 1956-1981 based on individuals with wages and salaries by amount of wage and salary) show a ratio of female to male median earnings of 36.4 (1956). 37.9 (1964), 41.3 (1971), 51.3 (1982), but this does not distinguish part-time and full-time earnings. Data reported for this study indicate that between 1980 and 1986 the female/male earnings ratio has drifted up by 6.4 percentage points from 63.9 to 70.3 .

While there may be a number of causes for this more recent shift, it is not likely at this stage that settlements flowing from federal legislation (amounting for example to $\$ 3138000$ in 1983) are among them. The five State and associated local legislative initiatives may be contributing somewhat to this measurable effect; the reported increase in pay equity as a collective bargaining issue would also be influential. Equal employment opportunity and affirmative action measures may be having some effect. However, recent analysis has pointed to a convergence in male and female employment patterns as largely responsible for a rise in the ratio of male and female median earnings (23). It has also been suggested that the impact of this trend on earnings has been partially masked by the rapid growth in participation rates with more and more women coming in at the bottom. Additional data would be of considerable use in analysing this effect.

The gradual trend in the Canadian figures toward the reduction of gender age differentials both precedes and follows the 1978 Human Rights Act: The effect of the Canadian legislation on pay ratios is not therefore clearly evident. It should however be noted that the Canadian legislation, which in the federal and a number of provincial sectors is still complaints-based. is incremental rather than across the board in its design. Significant exceptions to this generalisation are the Pay Equity Acts in some provinces, which require 
employers and employed groups to identify and correct discriminatory pay practices. This legislation applies at present to the public sectors in Manitoba, Nova Scotia, and Prince Edward Island, as well as to the Ontario public and private sectors. While it remains in the early implementation stages, it is unlikely to have any measurable effect on national pay ratios.

In New Zealand the female/male earnings gap narrowed from 72.1 per cent to 78.7 per cent during the period of implementation of the Equal Pay Act in the private sector $(1973 / 77)$. It has, however, remained static since that time at between 77.8 and 79.9 per cent. It appears, then, that the Equal Pay Act did affect women's earnings but that its effectiveness was restricted by a number of factors including both a generally acknowledged weakness in the legislative machinery and the limited interpretation placed on it by the Arbitration Court.

The most significant factor affecting the female/male earnings ratio in Portugal was the introduction of the minimum wage in 1974 . This was part of a policy aimed at raising the earnings of the lowest salaried workers and favouring the lowest social and occupational categories, most of which were occupied by women. Consequently, in 1974 and 1975 there was a tendency towards a convergence of men's and women's salaries; wage differentials between male and female non-rural workers decreased from about 50 per cent in 1973 to 28 per cent in 1975. Similarly, in agriculture, the wage differential - . which was 42 per cent in 1973 -. was reduced to 33 per cent in 1975. The earnings ratio did not vary more than 1.1 percentage points in subsequent data reported by Portugal. It does not accordingly appear that the 1979 legislation has had any significant impact in earnings.

Japanese data show a drop in female/male pay differentials between 1960 . when the differential was 56.6 per cent, and 1970 when the differential was 42.8 per cent. However, the ratio of women's to men's earnings worsened between 1975 and 1985 , from 58.1 per cent to 55.7 per cent. While there was no relevant legislation between 1947 and 1986, the 13.8 per cent rise in the earnings ratio between 1960 and 1970 may be linked to structural changes in women's employment, and in particular to a substantial shift away from traditional employment in agriculture (and to some extent from manufacturing as well) and towards wholesale and retail sales, finance, insurance and real estate, and services (24). The more recent decline may be due to a growing proportion of part-time workers with lower rates of pay.

The passage of the Japanese Equal Opportunity in Employment Law in 1985. which received much media coverage in Japan, has in some areas had an immediate impact: in Spring 1986, 72.9 per cent of firms surveyed by the Japanese Federation of Employers'. Associations had set starting salaries for women college graduates at the same level as those for men, compared with 44.6 per cent in the previous year. In 1987, starting salaries of new female university graduates were 96 per cent of corresponding salaries for males among clerical workers and 97 per cent among technical workers. A more widespread impact of this legislation will depend on the capacity to overcome obstacles, such as long-standing social customs and presonnel management practices.

Turkish data were not disaggregated by sex. Turkey reported broadly that wage discrimination on the ground of sex was not permitted according to Turkish Labour and State Personnel Acts. 
In Denmark. Finland and Sweden legislation does not appear to have had a discernible effect. In the case of the Finnish legislation, which came into force on 1 January 1987, it is simply too early to analyse any impact. In the cases of both Denmark and Sweden legislation post-dated highly influential collective agreements. In Denmark legislative provision came into force in February 1976 following settlements by collective agreement in 1971 and 1973 which had the effect of raising pay ratios for unskilled workers from 80.7 in 1971 to 90.0 in 1975 . Since the 1976 legislation the ratio for unskilled workers has actually fallen to 89.1 per cent (in 1986).

In Sweden a 1960 agreement between the Swedish Trade Union Confederation and the Swedish Employers' Confederation led to the abolition of specifically women's wages over a 5-year period. The female/male pay ratio for ordinary industrial workers rose from 68.8 in 1960 to 76.5 in 1966 and thereafter to 89.1 in 1979 . The introduction of pay equity legislation in 1980 has had no significant effect.

Similarly, in Australia pay ratios have been wholly shaped by industrial action and national wage fixation processes rather than by legislated standards and minima. While the 1969 equal pay decision affected only an estimated 18 per cent of women who were doing the same work as men, the 1972 decision calling for equal pay for work of equal value and the 1974 extension of the minimum wage to women were highly influential. Because, however, the 1972 decision was in practice implemented over a period of several years (and is still available for implementation), and because the introduction of the minimum wage for women coincided with the early phase of the implementation period, it is not possible to isolate the impact of each of these decisions on pay ratios for full-time workers. Clearly, however, the cumulative effect of the decisions was substantial, raising the female/male pay ratio from 68.9 in 1972 to 81.0 in 1978 . Since that time there has been only very slight change.

In Canada, the United States and Great Britain, where the wage fixing system is not centralised, the impact of collective bargaining for equal pay for work of equal value is, comparatively speaking, diffused. It is notable. however, that in two of these countries there is a continuing drift upward in the female/male ratios which may correspond to a reported increase in interest and activity in local and workplace collective bargaining in these countries.

Overall, then, it appears that in relatively decentralised systems legislation may prove effective in reducing wage gender differentials. At least there is a correlation between legislation and such a reduction in Great Britain. It is equally arguable that the effectiveness of the British legislation lay in that part of its provision which applied across the board to collective agreements and in the absence of complex complaint-based processes found in other legislation (such as that in the United States) which has had no evident impact on pay ratios. However, it does not by any means follow that any ineffectiveness of complaint-based legislation lies in legislating itself, and not in particular pieces of legislation. In addition. the present drift upward in pay ratios in the United States and Canada corresponds with impressions reported from these countries that legislation is increasingly having an influence on collective bargaining processes. 


\section{Women's Horkforce Participation}

As Table 3 indicates, women's workforce participation rates have continued the substantial upsurge experienced since the war. Among participating countries, these rates grew by an average of 13 per cent between 1973 and 1986. varying from 3.4 per cent in Japan to 24.1 per cent in Portugal. As is generally recognised, much of this employment growth has been in part-time work and in segregated occupations for example in service industries, which in Australia account for the largest share of total employment and an even larger share of employment growth over recent years.

If full-time workers' earnings only are considered there is some relationship between women's increasing participation in the workforce and the reduction of gender wage differentials. There are a number of reasons why this may be the case, including:

- Increasing pressure from women's lobbies on governments, resulting in equal employment opportunity, affirmative action and equal pay legislation, and in appropriate education, training and skills recognition facilities;

- Recognition of economic advantages inherent in improving labour market flexibility and widening the skills base:

- Women's reduced periods out of the workforce with corresponding returns at higher skill/status levels;

-- The growing interest of unions in increasing women's membership through attention to women's interests, including equal pay, and through increasing the representation of women at executive levels; and

- Overall, a general expansion in employment opportunities.

There may also have been a direct relation between increasing female work force participation and rising wages for women, in that over time it has in some areas become more economically advantageous or necessary for women to work. Interestingly, it has been suggested that the continuing low elasticity of substitution between women and men in the production process has meant that changes in pay relativities have exhibited no significant effect on relative employment (25).

The degree of occupational segregation and its fixed nature have also meant that the characteristic pattern of women's workforce participation has remained relatively stable in the face of significantly growing participation rates. A very recent development has been the growing Government interest in taking active measures to reduce occupational segregation. Two current considerations underpinning such thinking are:

- The advantage of a more broadly-based workforce for responding to economic pressures exerted by ageing populations; and 
- The acknowledged desirability of a widened skills base for responding efficiently to the requirements of continuous industrial restructuring.

Despite government initiatives it can be expected that measures to reduce occupational segregation will have little short-term effect, and the necessity for implementing pay equity across occupational groups will remain. In fact the implementation of equal pay initiatives may assist governments in reducing occupational segregation.

\section{vI. CONCLUSION}

The data reported are insufficient to support confident conclusions. In some cases, there are problems in comparing data; in some cases impact may be gradual and cumulative and referable to a number of simultaneous causal factors. Broadly it can be reported that:

- pay equity has not been achieved:

-. in terms of institutional mechanisms, a comparatively centralised wage-fixing system is a more efficient vehicle for implementing equal pay initiatives;

- while national wage-fixing systems are not likely to alter significantly, much can be done through legislation to reduce pay inequity; and that

- across the board initiatives raising the earnings floor are most effective in reducing sex-based differentials, whether they take the form of legislation as in Britain or industrial initiatives such as the Wage Solidarity policy in Sweden.

It also appears to be the case that legislative actions directed to achieving equal pay have a number of separate roles in relation to industrial activity. This role is most clear in the case of legislation such as that in Portugal whereby collective agreements cannot be extended throughout an industry if they do not observe pay equity principles. In this case the legislation establishes a monitoring role (which can be either active and systematic or passive and complaints-based) in relation to collective agreements. Legislation also may:

- assist in floor-raising, exercised as in British legislation;

- directly stimulate collective bargaining for equal pay, as in the State of Minnesota (US), or

- become an important collective bargaining lever, as is reported to be increasingly the case in Great Britain, or 
- become a sign of the political climate surrounding equal pay and related anti-discrimination issues, and thus indirectly affect the degree and effectiveness or industrial activity:

Thus the difficulty of the British legislation, and the increasingly successful reliance of United States employers in comparable worth cases on the 'market factors' and 'discriminatory intent' defences coupled with the absence of any legislative initiatives to clarify these matters, may have affected the attitudes in individual workplaces to pay equity initiatives. Clear legislation incorporating simple judicial mechanisms represents, in addition to its practical effectiveness, a sign of government intentions in relation to equal pay.

The Canadian Human Rights Act appears the most effectively designed of the legislation considered here on a number of grounds:

- Through Section 11 of the Canadian Human Rights Act there is a clear statement of what is meant by equal pay, how pay is defined and what is considered discriminatory; and therefore ambiguities in definition of pay and the applicability of the concept are minimised.

- The Canadian Human Rights Commission has a crucial role in enforcing the legislation. In addition, prior to its active involvement in implementing the legislation, wages specialists were taken into the Commission and given six months of specialist training in the issues and on how to handle implementation.

- The Commission has produced comprehensive guidelines for employers and unions on how it should be implemented/how to assess jobs and so on.

- The Canadian model tends to use negotiation and conciliation first and then legal redress if necessary. However, this is partly a reflection of the Commission's ability to intervene and review settlements.

The Canadian Human Rights Act remains, however, like all the national legislation considered, a complaints-based system relying on the filing of a complaint in order to trigger enforcement of the prohibitions contained in the legislation. A complaints-based system is usually grounded on the assumption that violations are the exception, not the rule. If the alternative assumption is made, namely that wage discrimination against women is endemic to the system and requires a systemic remedy, then a regulatory rather than a complaints-based legislative model is required. Such a model places direct obligations on employers to study their own pay practices and ensure that such practices comply with the legislation. Labour Canada's Equal Pay Program was instituted to ensure that employers are in compliance with the equal pay provisions of The Canada Labour Code and The Canada Human Rights Act.

Such legislation already exists to varying extents at State/provincial and local levels in the United States and Canada - in Minnesota, Iowa, Oregon, Washington, California, Manitoba and Ontario. The process in Manitoba has been characteristic. 
In 1985, Manitoba passed Canada's first pro-active pay equity legislation. The first stage required a co-operative process between the Public Service and the Manitoba Government Employees' Association to identify and correct discriminatory pay practices. Together, they selected a system of job evaluation, identified the job classes for inclusion in the process, and compared jobs in female-dominated classes with jobs of equal value in male-dominated classes. When skill, effort, responsibility and working conditions were evaluated, a woman's salary was adjusted if her wage was lower than a man whose job was of comparable value. Men working in traditionally. female occupations also benefit from the wage adjustments. Over the next four years, the province will inject $\$ 16$ million, or 4 per cent of the total payroll, into salaries of 60 per cent of the women in the Public Service. The provincial government has in addition made commitments to extend pay equity to the broad public sector and to the private sector.

An'. increase in union sponsored activity for equal pay for work of equal value, particularly in association with pro-active legislation of the sort being developed in a local basis in North America, appears to offer one useful pattern for future institutional development, particularly in relatively decentralised wage-fixing systems.

In relatively centralised systems legislation can require industrial courts to take pay equity issues into account on an analogy with Australian legislation establishing the Industrial Relations Commission, or it can restrict the applicability of awards across industries as in the case of Portugal. In these cases there also arises the question of whether legislation is pro-active or complaints based, that is, whether there is a specialist monitoring body and what its role may be.

In conclusion, due to wage-setting patterns at the turn of the century, women's work has been devalued. This devaluation continues to be associated with occupational segregation, and has led many governments to introduce through legislative and industrial processes measures to provide pay equity for women.

This paper has illustrated the limitations of existing measures to achieve pay equity for some groups. There are, however, indications that more comprehensive methods are being developed and implemented to assist in the correction of past discrimination. 


\section{NOTES AND REFERENCES}

1. See Paul Miller and Sarah Rummery, "Gender Wage Discrimination in Australia: A Reassessment," unpublished paper, Department of Economics, University of Western Australia, 1989.

2. Australia; Belgium; Canada; Denmark; Finland; Greece; Japan; New Zealand; Portugal; Sweden; Turkey; United Kingdom; United States.

3. This study is quoted in OECD. Employment Outlook 1988, Chapter 5, p. 154 .

4. 6 (Australian) Commonwealth Arbitration Report 71.

5. 1922 Arbitration Court Judgement, quoted from Prue Hyman, "The Fight for Equal Pay for Work of Equal Value (Comparable Worth) in New Zealand," Paper for Seventh Berkshire Conference on the History of Women, Wellesley College, Wellesley, Massachusetts, June, 1987, p. 2.

6. Canadian Labour Gazette 1918 a: 617.

7. Editorial, Focus on Canadian Employment and Equality Rights, Vol. 1. No. $20(1987)$, p. 152.

8. Based on the decision in County of Washington V. Gunther, 452 U.S. 161. 26 EPD 31, 877 (1981).

9. Drawn extensively from Mary Cornish, "Equal Pay: Collective Bargaining and the Law," Background paper for a seminar organised by the Canadian Women's Bureau on Equal Pay: Collective Bargaining and the Law. November, 1986. pp. 17-21.

10. 149 (Australian) Commonwealth Arbitration Report 178.

11. 147 (Australian) Commonwealth Arbitration Report 172.

12. See Elizabeth Orr. "The Arbitration Court's Role in Supervising the Equal Pay Act 1972, "Center for Continuing Education, Victoria University of Wellington, April 1986.

13. See NZ Clerical, etc, IAW v Farmers Trading Company Limited and others, 28 February 1986. Arbitration Court (AC24/86) Judge Finnigan. Messrs Cameron and Weir.

14. P.J. Hyman, and A. Clark, Equal Pay Study: Phase One Report, Department of Labour, Wellington, 1987, p. 45. 
15. International Labour Conference 1986, Equal Remuneration. General Survey by the Committee of Experts on the Application of Conventions and Recommendations. International Labour Office Geneva, 1986, p. 177.

16. See QECD Employment Outlook 1988, Chapter 5, Section B.

17. Drawn extensively from Cornish, op. cit, 23-27.

18. Research drawn on here is considered at length in Clare Burton, Raven Hag and Gay Thompson. Women's Worth (Canberra: Australian Government Publishing Service, 1987), Chapter 7.

19. See R.G. Gregory, R. Anstie, A. Daly and V. Ho, "Women's Pay in Australia, Britain and the United States: The Role of Laws, Regulations and Human Capital". Draft Paper for Panel on Pay Equity Research, National Research Council, Washington, September, 1987. pp. $31-32$.

20. M.W. Snell, P. Glucklich and M Povall, Equal Pay and Opportunities: A study of the implementation and effects of the Equal Pay and Sex Discrimination Acts in 26 organisations (London, 1981) pp. $18 \mathrm{ff}$.

21. Gregory et. al., op. cit, 13-17.

22. See F. Blau and M. Ferber, The Economics of Women. Men and Work (Englewood Cliffs, 1986).

23. QECD Employment Outlook 1988, Chapter 5, Section I.4.

24. See Nabuko Takahashi, "Women's Employment in Japan in a Period of Rapid Technological Change", International Labour Review, Vol. 98, No. 6 (December 1968), p..495.

25. Sandra Eccles, "The Role of Women in the Labour Market: A Survey of the Literature," in B.J. Chapman, J.E. Isaac and J.R. Niland (Eds). Australian Labour Economics: Readings, 3rd. Ed. (Melbourne, 1984), pp. 590-91. 
Table 1

Dissimilarity indices of male and female employment distribution by major occupational groups*

Percentages

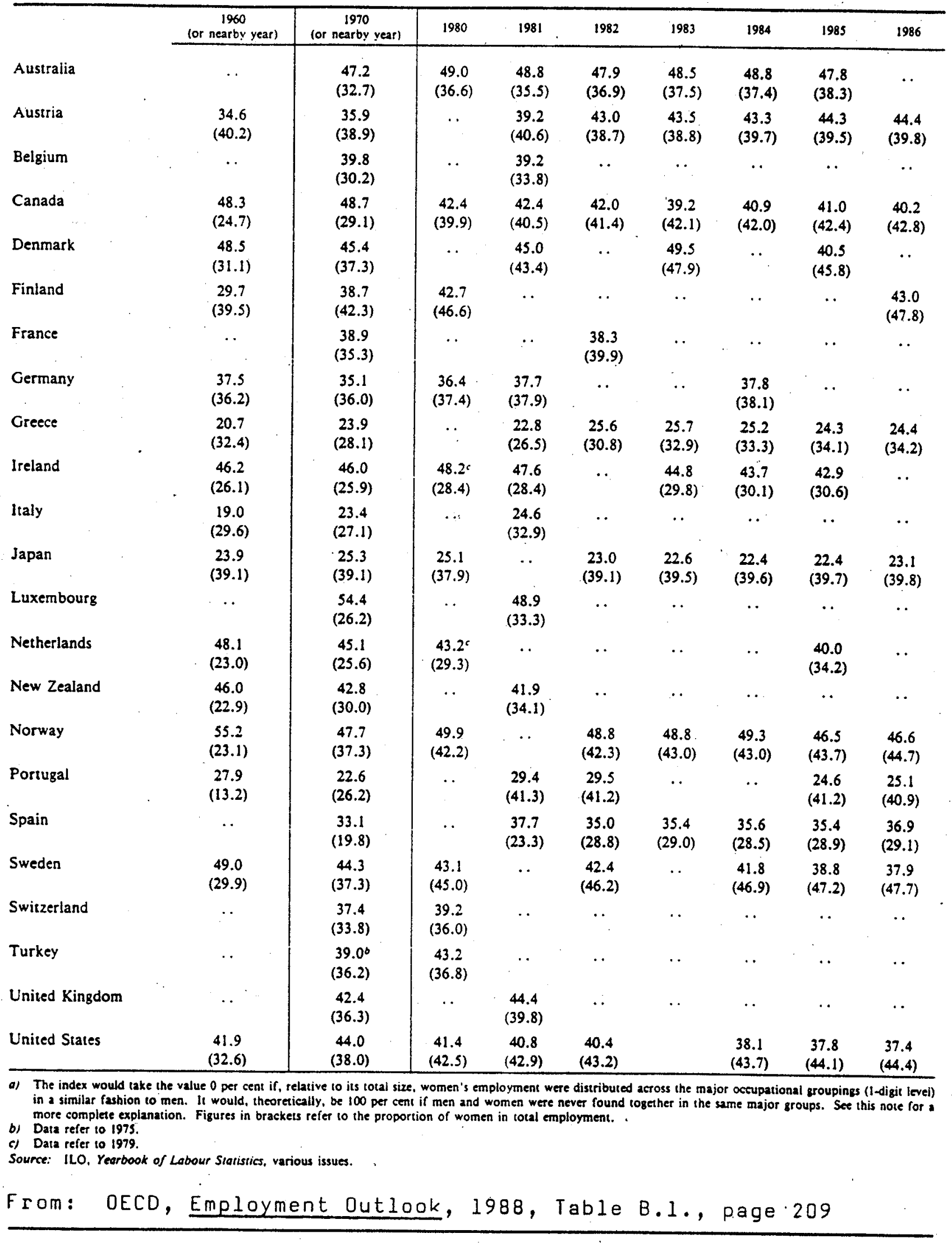


TABLE 2

RATIOS OF FEMALE TO MALE HOURLY EARNINGS FOR

MANUAL WORKERS IN MANUFACTURING

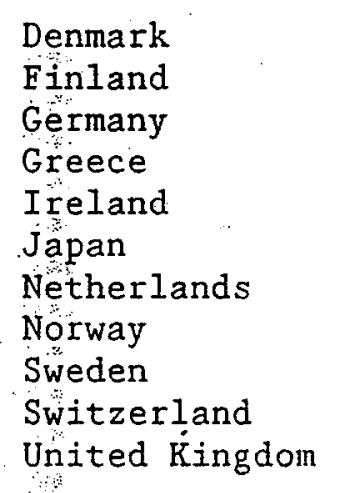

$\underline{1955} \underline{1965} \quad \underline{1975} \quad \underline{1985}$

$\begin{array}{lll}.653 \quad .716 & .843 \quad .856\end{array}$

$\begin{array}{llll}.676 & .681 & .726 & .768\end{array}$

$\begin{array}{llll}.628 & .688 & .721 & .727\end{array}$

$\begin{array}{lll}.621 & .695 & .776\end{array}$

$\begin{array}{llll}.564 & .567 & .609 & .682\end{array}$

$\begin{array}{llll}.447 & .519 & .512 & .486\end{array}$

$\begin{array}{llll}.588 & .669 & .792 & .777\end{array}$

$\begin{array}{llll}.674 & .720 & .780 & .835\end{array}$

$\begin{array}{llll}.692 & .749 & .852 & .898\end{array}$

$\begin{array}{llll}.637 & .627 & .660 & .671\end{array}$

$\begin{array}{llll}.585 & .568 & .665 & .682\end{array}$

Source: OECD, 1988 Employment Outlook, Table C.1, page 212. 
TARTE 3

WOMEN'S LABOUR FORCE PARTICTPATION RATES 1970-1987 (PRR CENT)

$\begin{array}{lccccccc} & 1970 & 1973 & 1979 & 1983 & 1985 & 1986 & 1987 \\ \text { Australia } & 46.5 & 47.7 & 50.3 & 52.1 & 54.1 & 56.4 & 57.5 \\ \text { Canada } & 43.2 & 47.2 & 55.5 & 60.3 & 62.8 & 64.0 & 65.4 \\ \text { Dermark } & 58.0 & 61.9 & 69.9 & 74.2 & 74.5 & 76.5 & 75.9 \\ \text { Finland } & 61.4 & 63.6 & 68.9 & 72.7 & 73.7 & 73.5 & 72.9 \\ \text { Germany } & 48.1 & 49.6 & 49.6 & 49.7 & 50.3 & 51.3 & 52.1 \\ \text { Greece } & - & - & 32.8 & 40.04 & 41.8 & 41.6 & - \\ \text { Japan } & 55.4 & 54.0 & 54.7 & 57.2 & 57.2 & 57.4 & 57.8 \\ \text { New Zealand } & 37.5 & 39.2 & 45.0 & 45.7 & 47.6 & 63.0 & \text { (a) } \\ \text { Norway } & 38.8 & 50.6 & 61.7 & 65.5 & 68.0 & 71.0 & 72.3 \\ \text { Portugal (b) } & 30.8 & 32.1 & 57.3 & 60.1 & 57.4 & 56.2 & 57.4 \\ \text { Sweden } & 59.4 & 62.6 & 72.8 & 76.6 & 77.6 & 78.3 & 79.4 \\ \text { Turkey } & 57.4 & (55.4)(\mathrm{c}) & - & - & - & - \\ \text { United Kingdom } & 50.7 & 53.2 & 58.0 & 57.2 & 60.6 & 61.6 & 62.6 \\ \text { United States } & 48.9 & 51.1 & 58.9 & 61.8 & 63.8 & 64.9 & 66.0\end{array}$

(a) New series started in 1986. New Zealand reports that a figure of 49.6 for 1986 can be compared directly to previous years' figures.

(b) Data concerning working population include a considerable rumber of persons aged less than 15 years and 65 years and over.

(c) 1975

Source: OECD, Labour Force Statistics 1967-87; Quarterly Labour Force Statistics. 


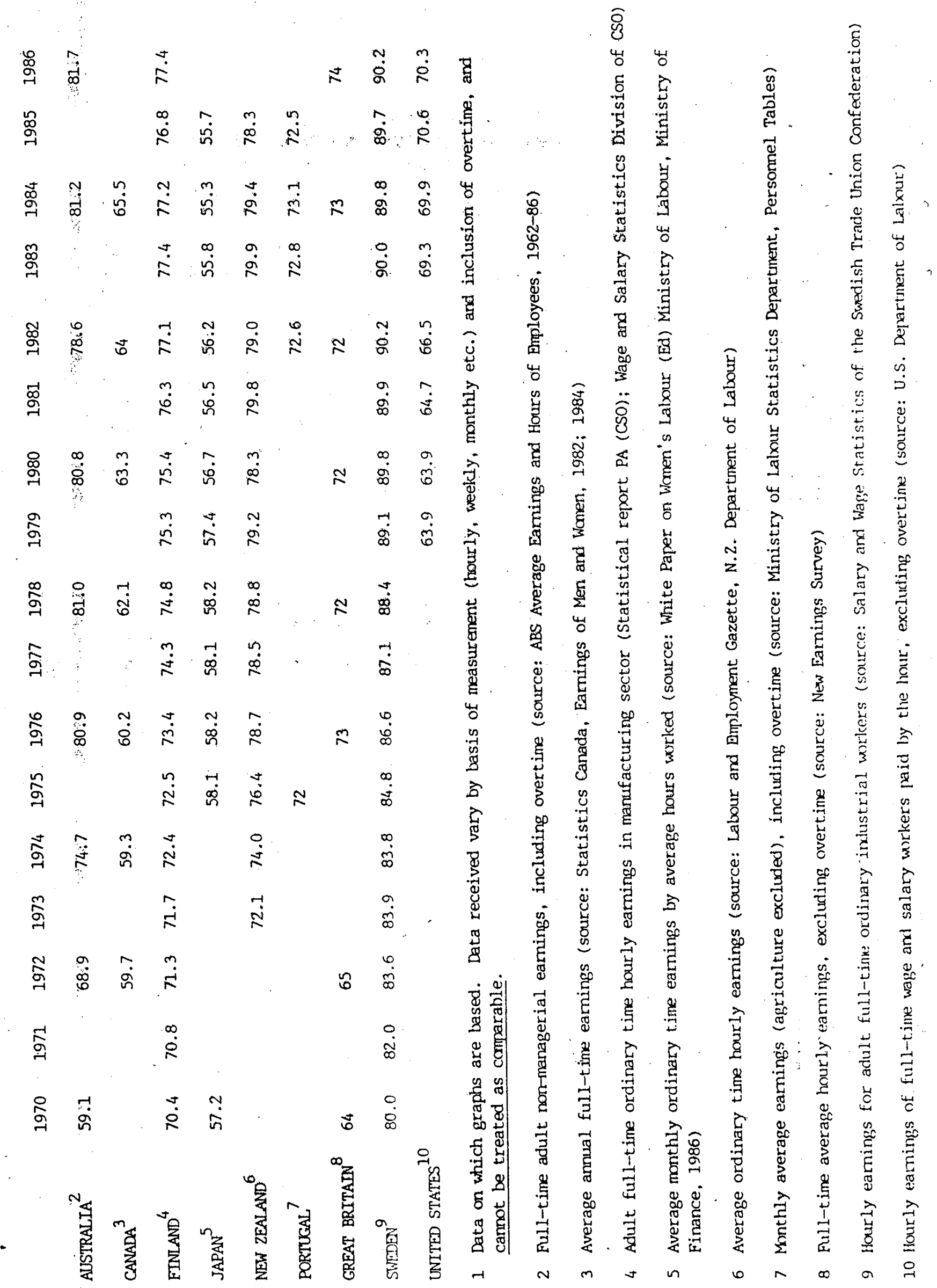




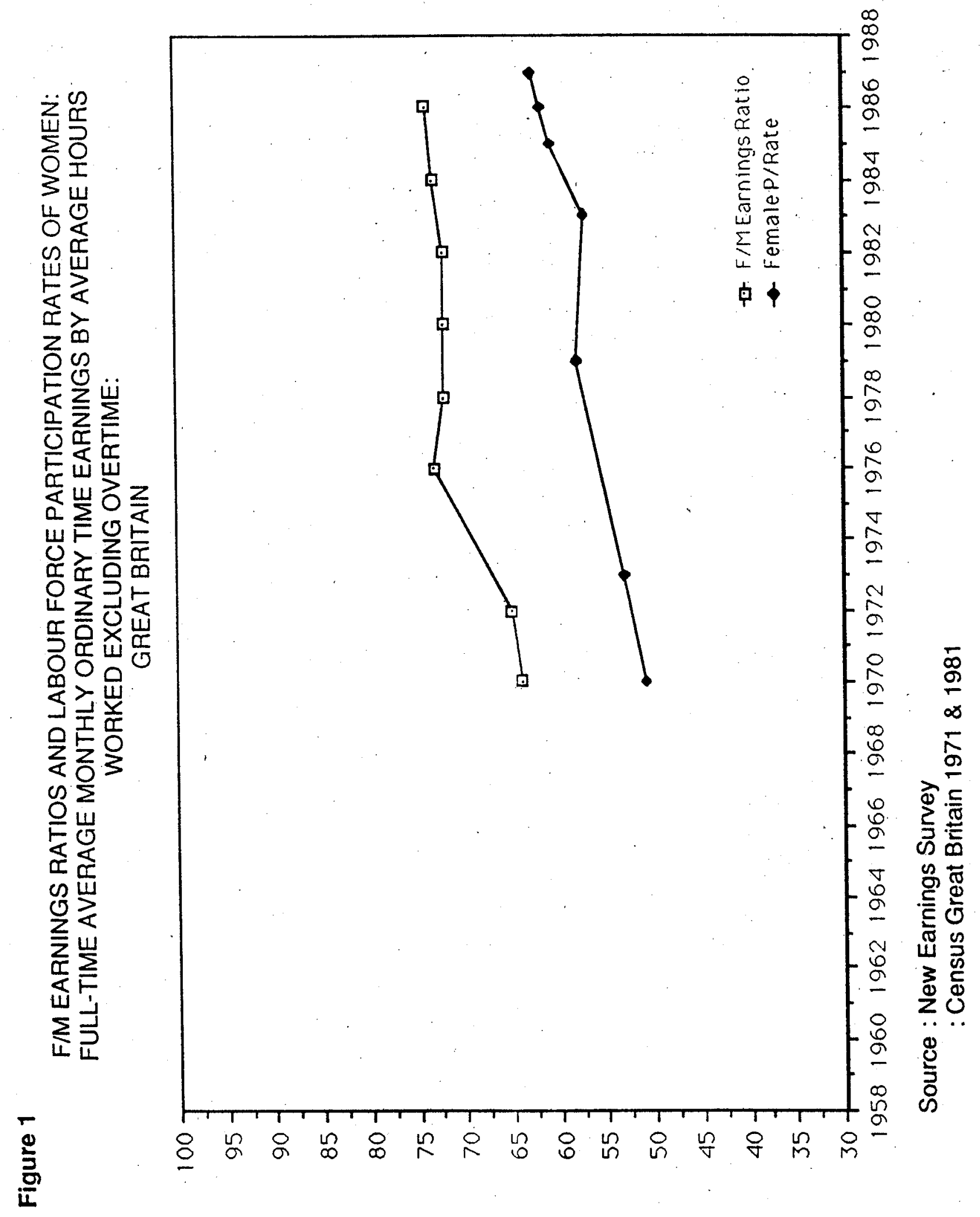




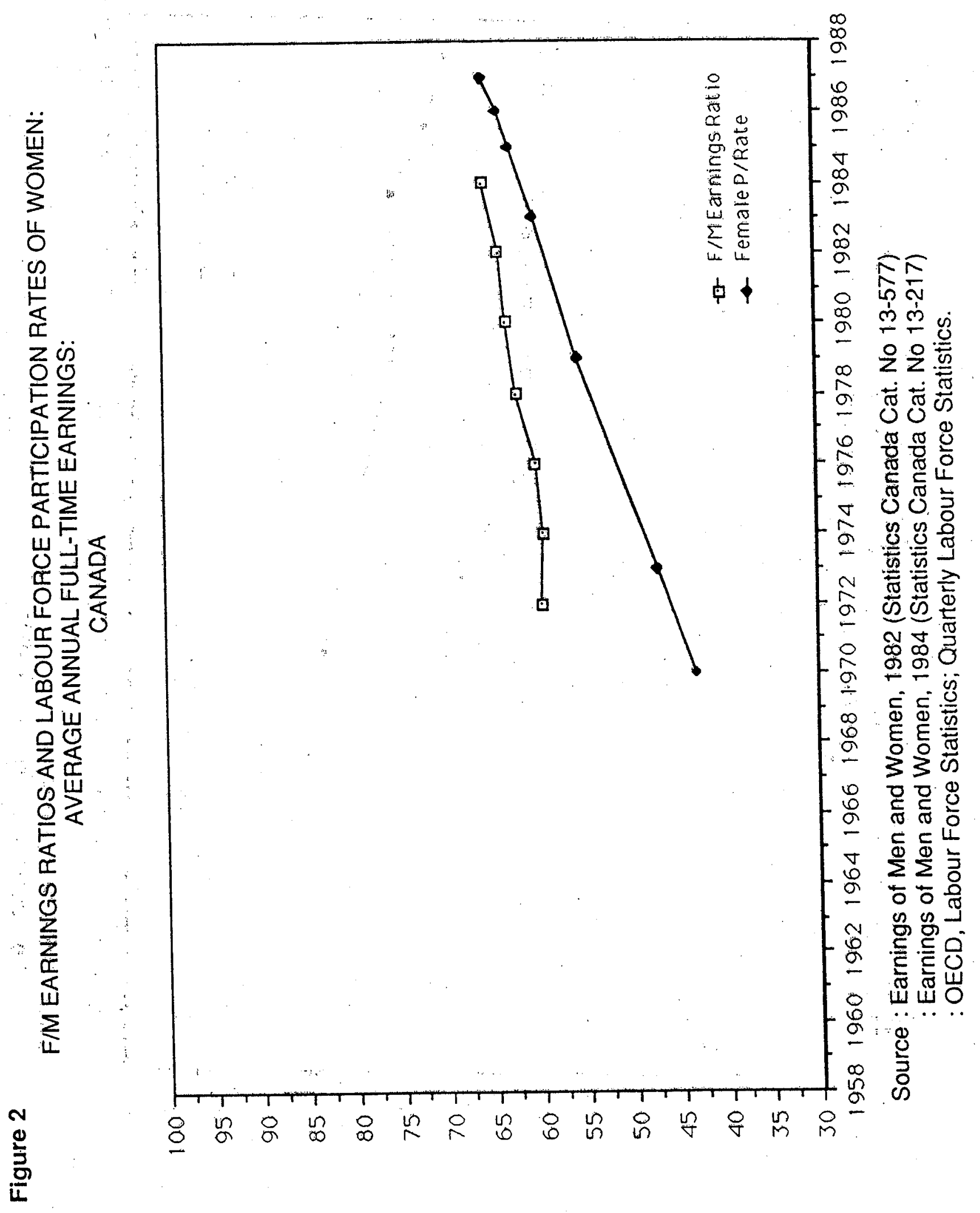




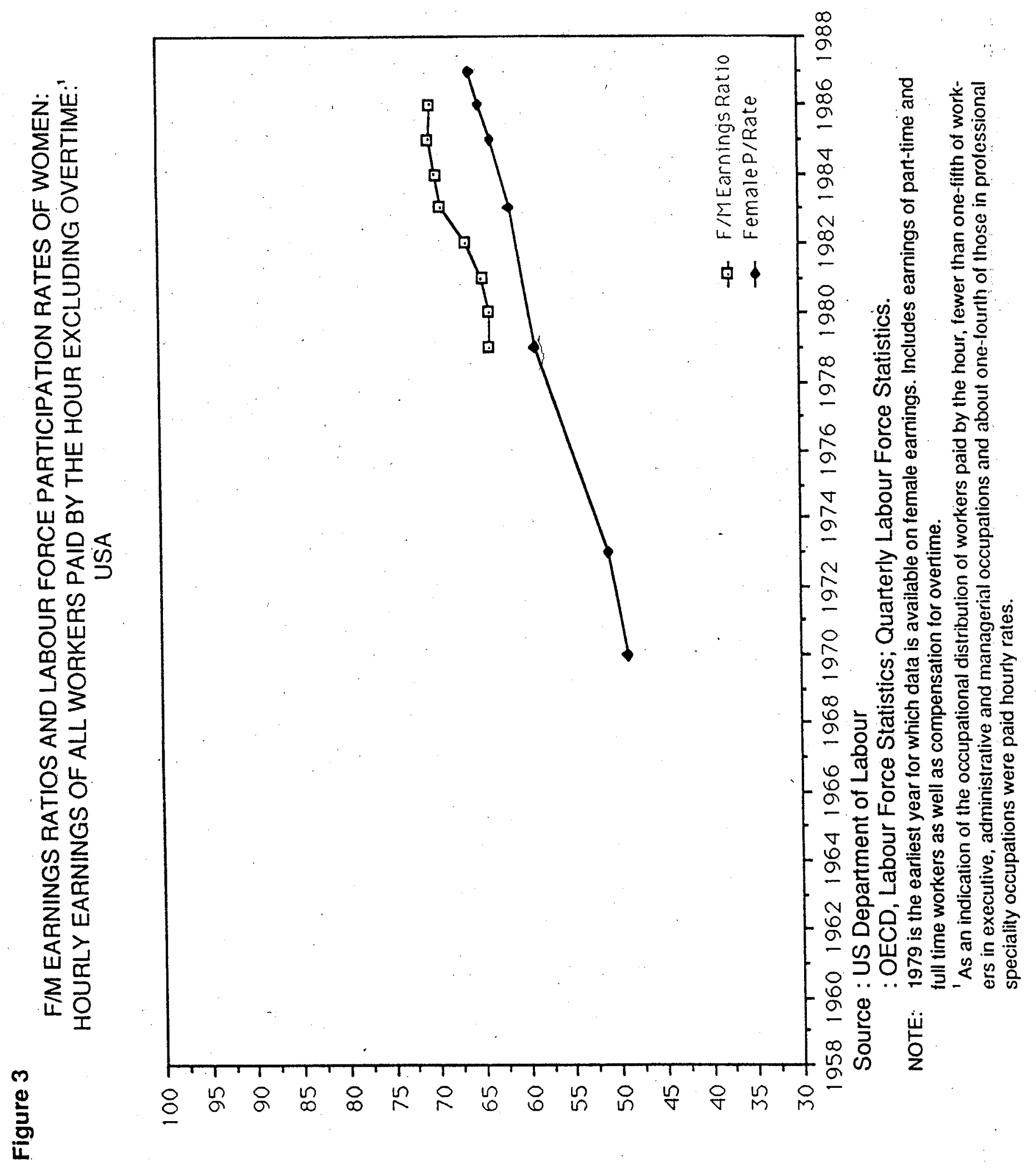




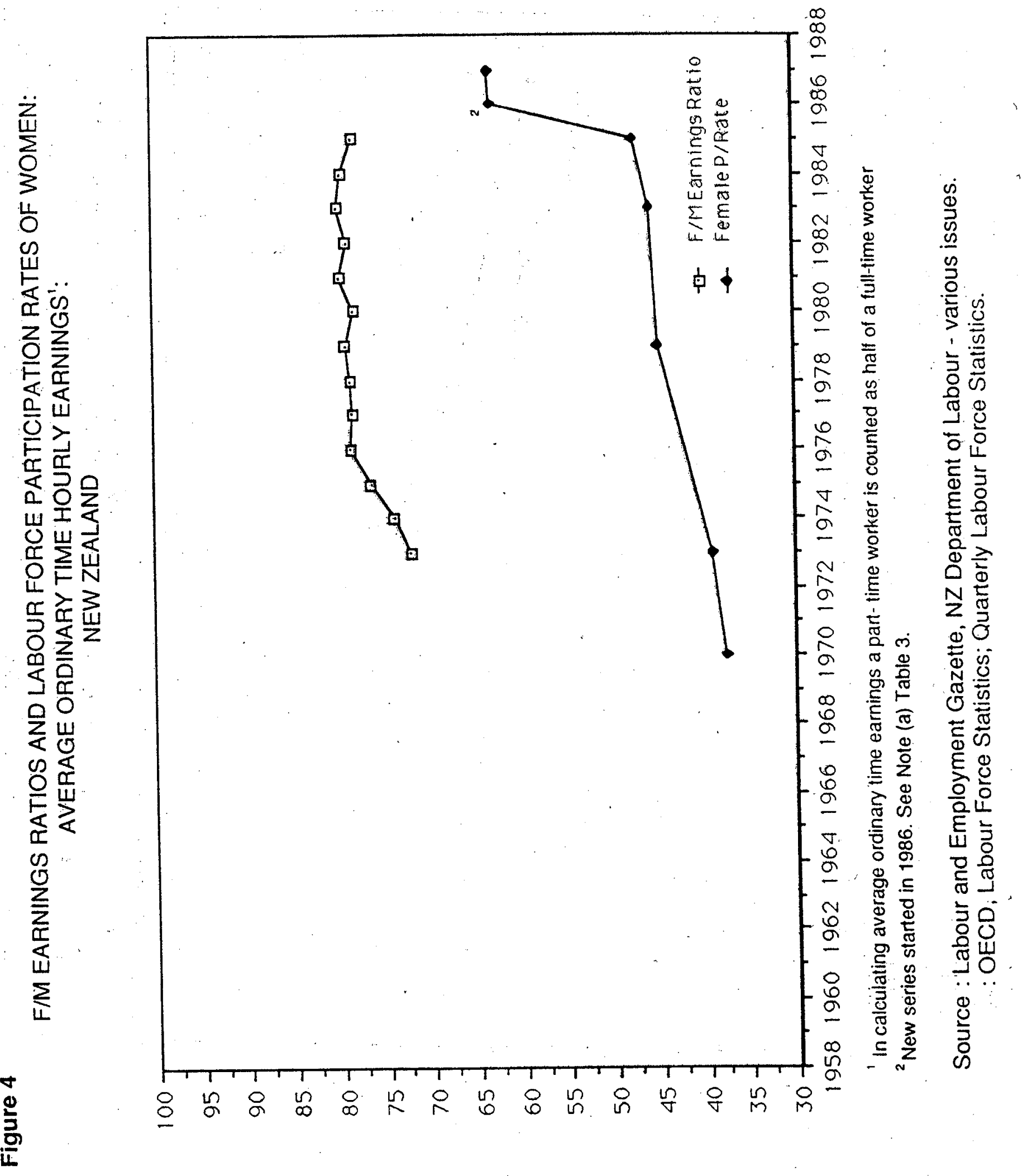




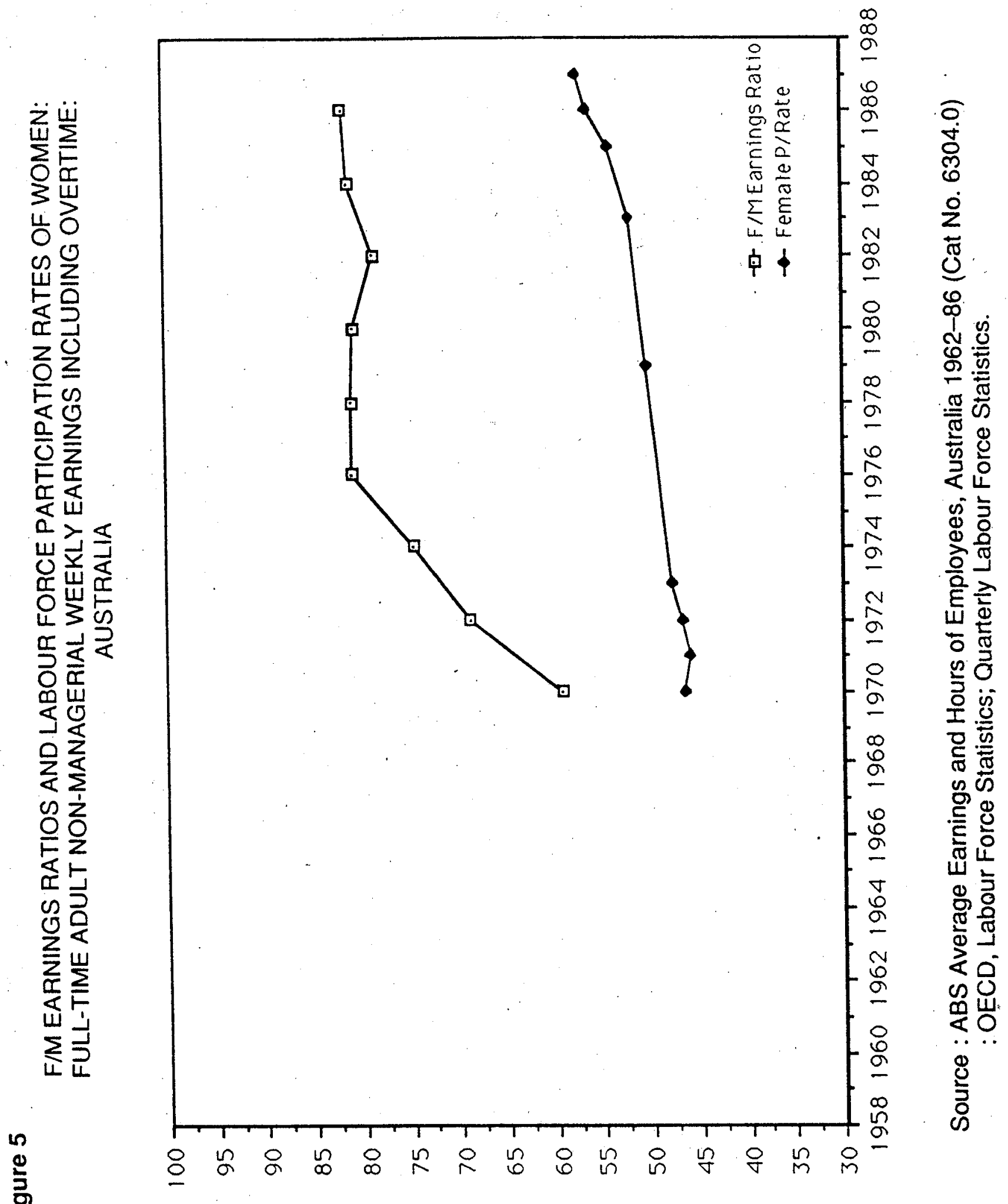




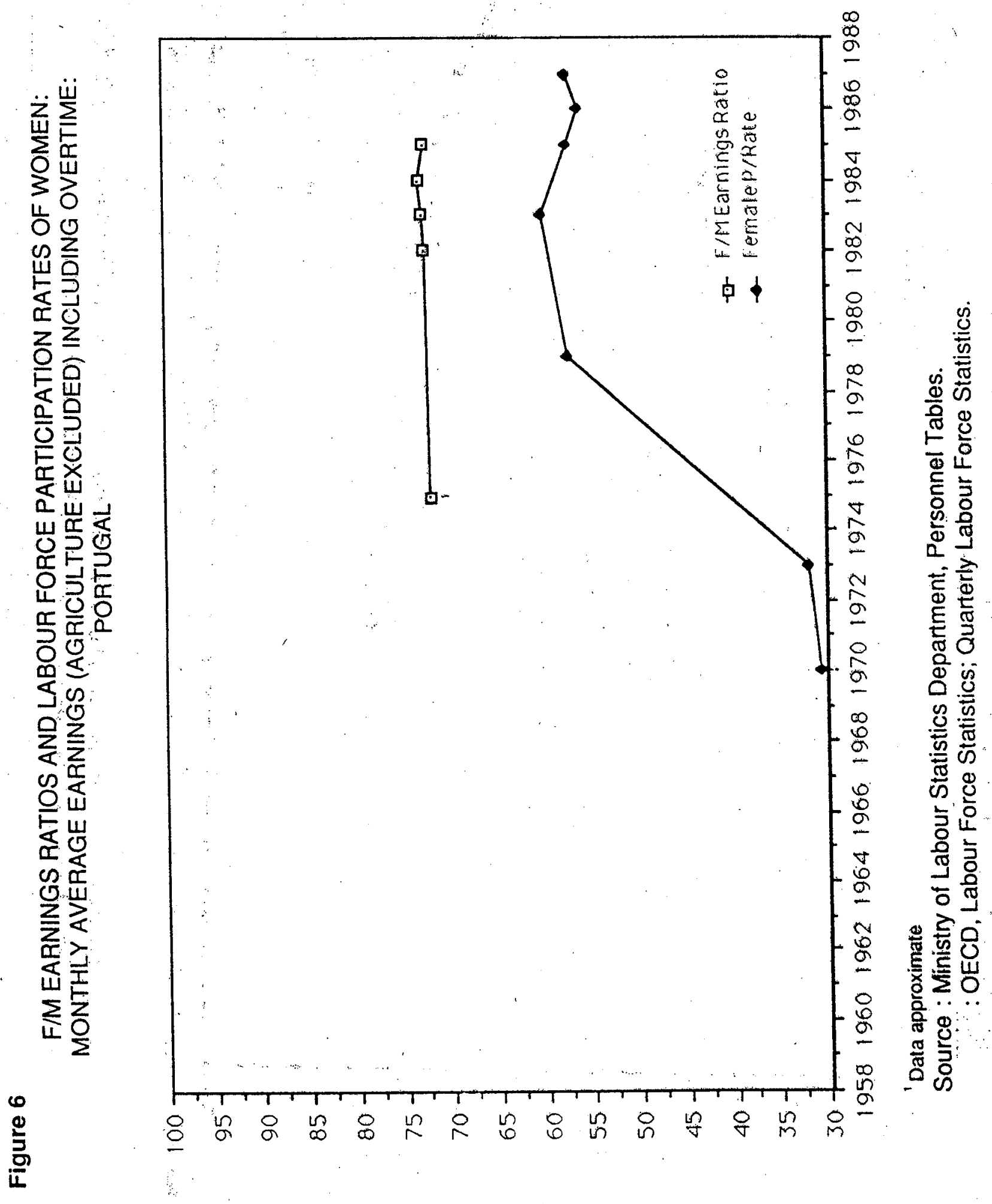




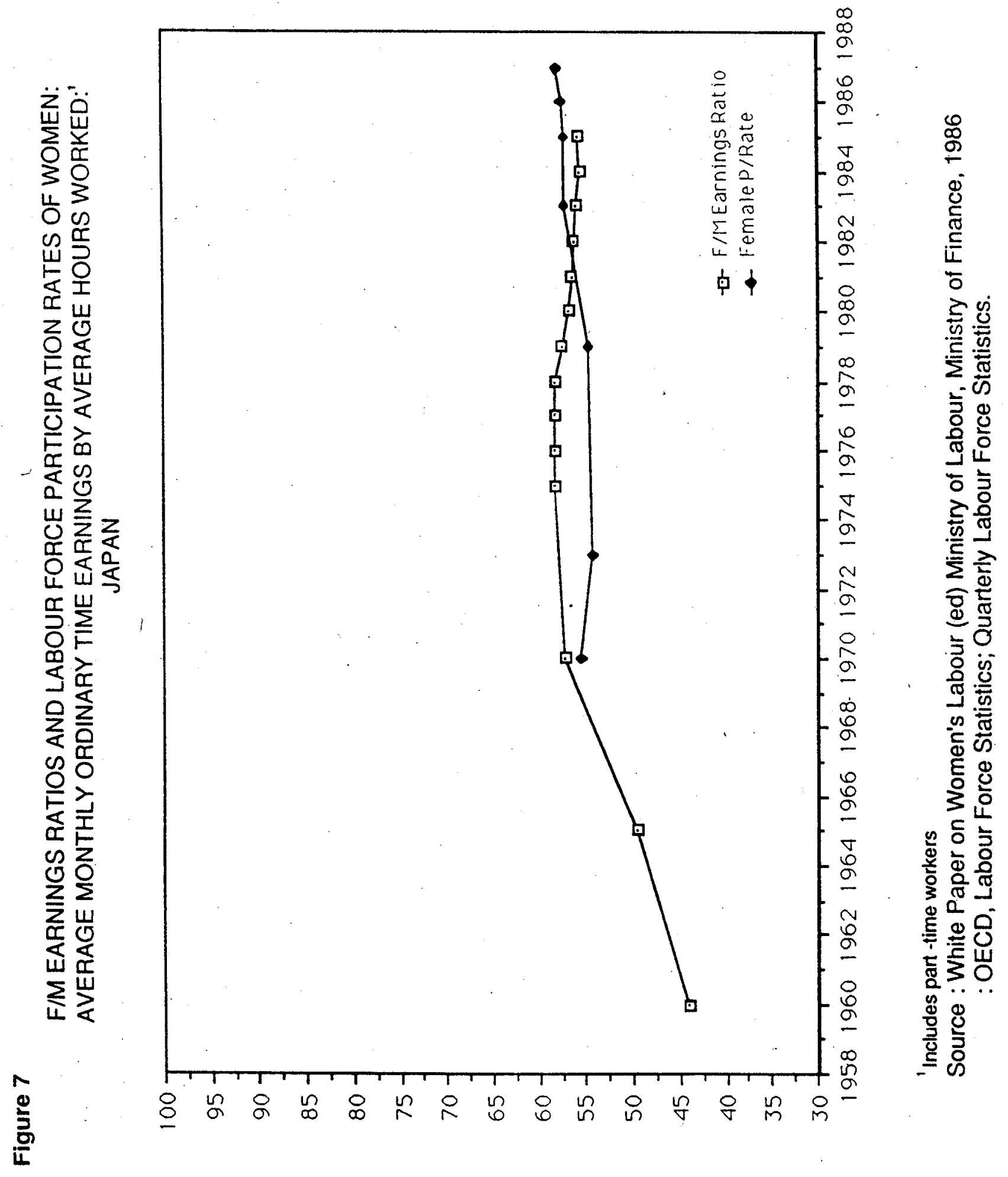




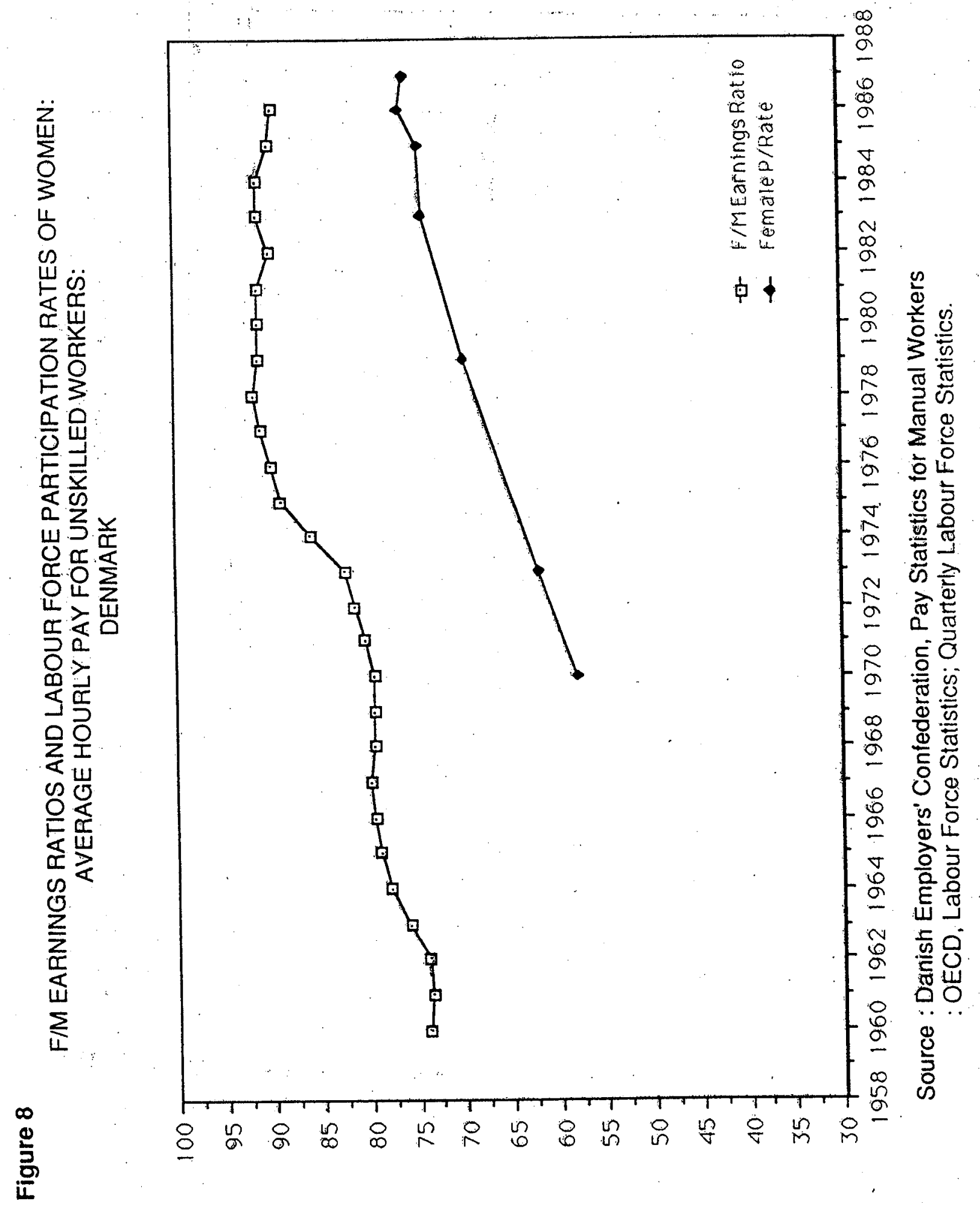




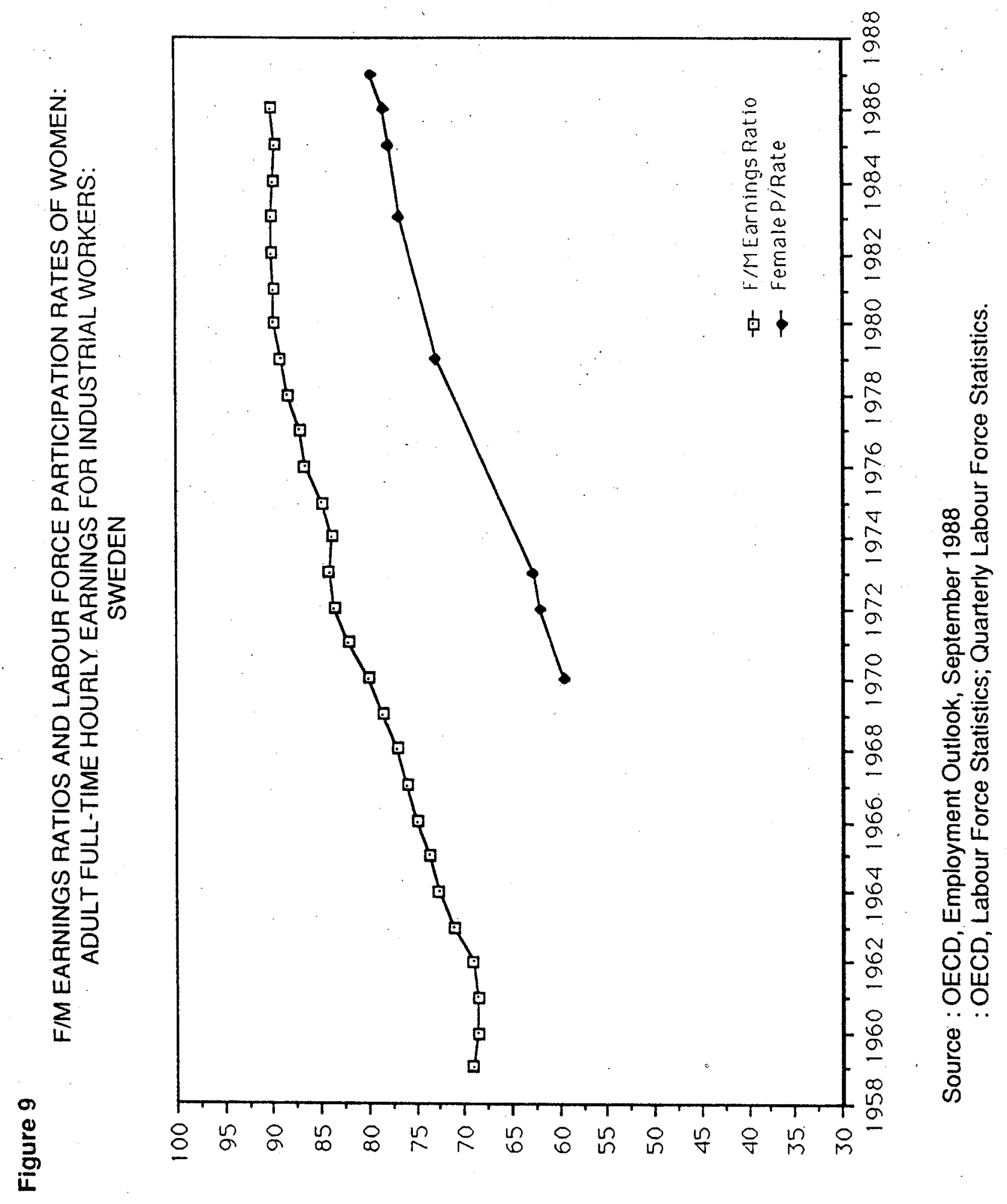




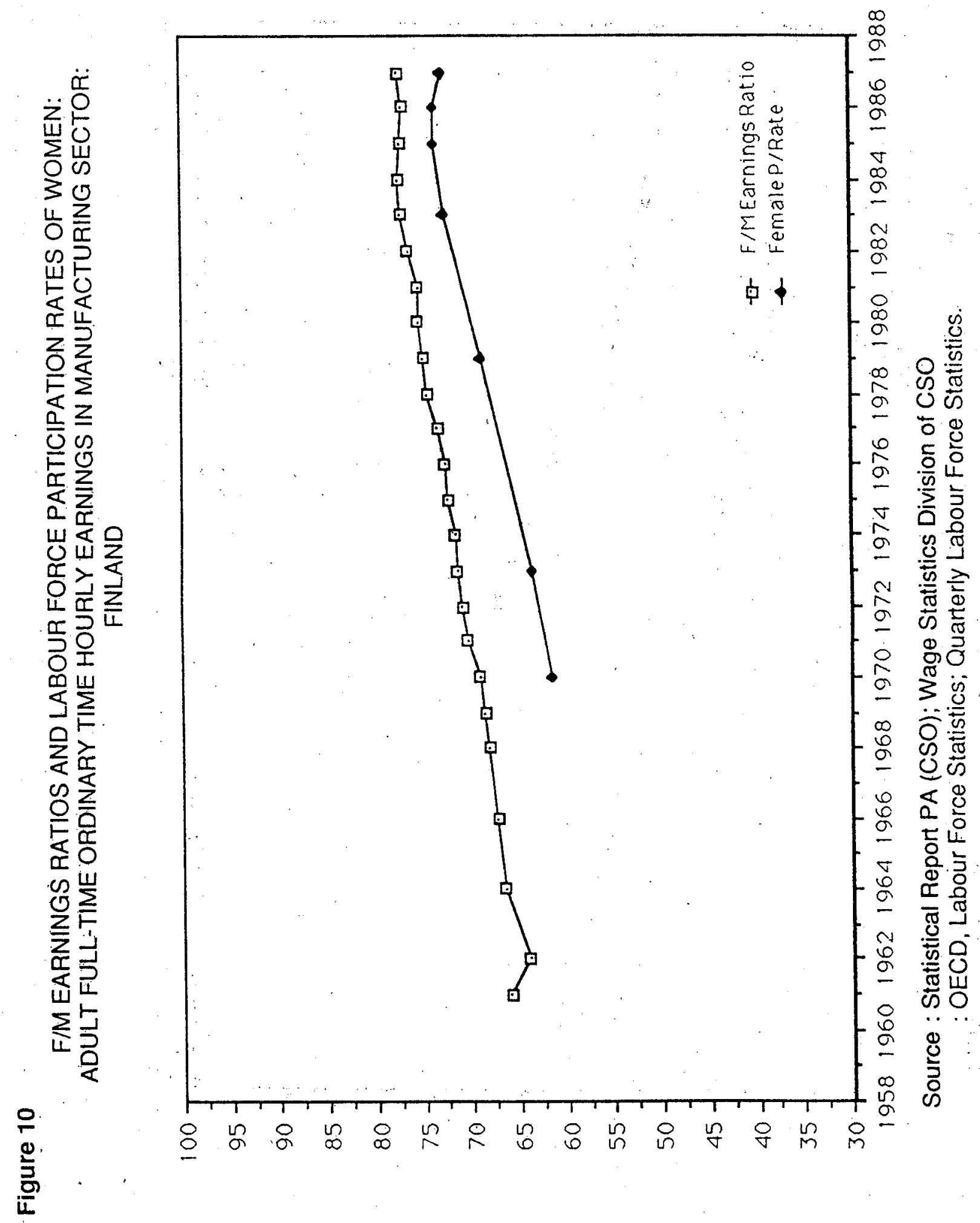




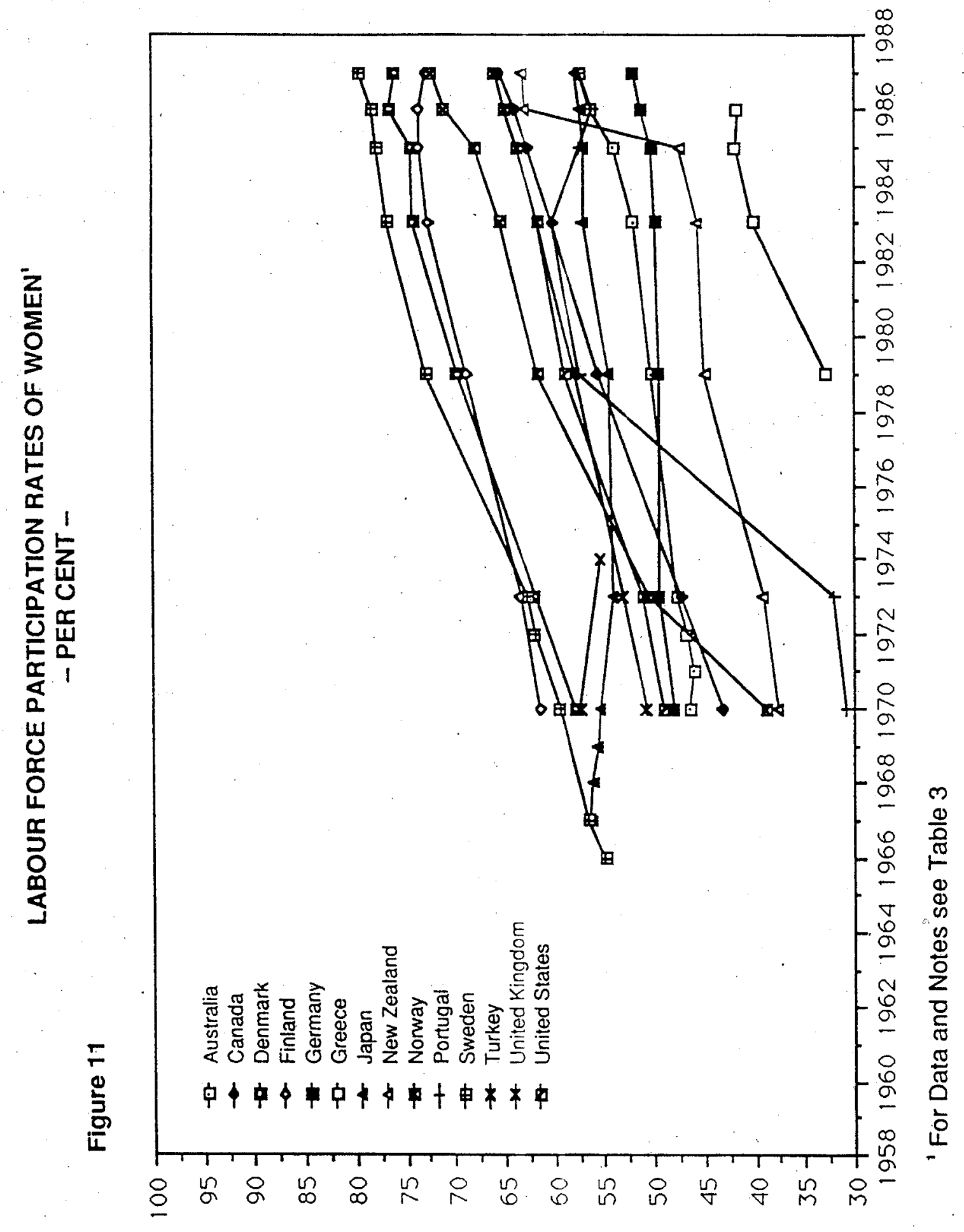




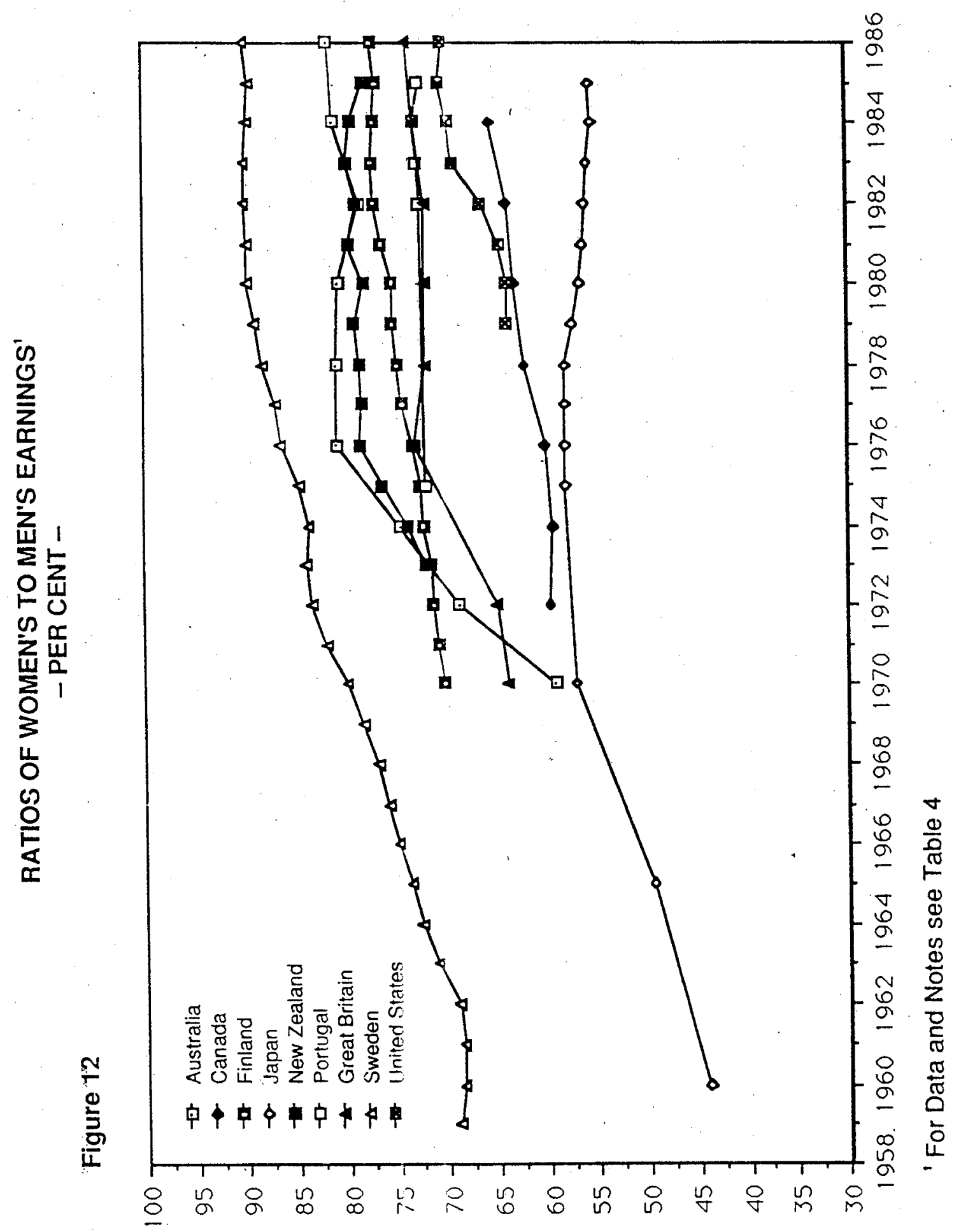

